\title{
Enzymes for $N$-Glycan Branching and Their Genetic and Nongenetic Regulation in Cancer
}

\author{
Yasuhiko Kizuka and Naoyuki Taniguchi * \\ Disease Glycomics Team, Systems Glycobiology Research Group, Global Research Cluster, RIKEN, \\ Wako 351-0198, Japan; y.kizuka@riken.jp \\ * Correspondence: dglycotani@riken.jp or rvw.tani@sanken.osaka-u.ac.jp; Tel.: +81-48-467-9616 \\ Academic Editor: Franz-Georg Hanisch \\ Received: 23 March 2016; Accepted: 21 April 2016; Published: 28 April 2016
}

\begin{abstract}
N$-glycan, a fundamental and versatile protein modification in mammals, plays critical roles in various physiological and pathological events including cancer progression. The formation of $\mathrm{N}$-glycan branches catalyzed by specific $\mathrm{N}$-acetylglucosaminyltransferases [GnT-III, GnT-IVs, GnT-V, GnT-IX (Vb)] and a fucosyltransferase, Fut8, provides functionally diverse $N$-glycosylated proteins. Aberrations of these branches are often found in cancer cells and are profoundly involved in cancer growth, invasion and metastasis. In this review, we focus on the GlcNAc and fucose branches of $\mathrm{N}$-glycans and describe how their expression is dysregulated in cancer by genetic and nongenetic mechanisms including epigenetics and nucleotide sugar metabolisms. We also survey the roles that these $\mathrm{N}$-glycans play in cancer progression and therapeutics. Finally, we discuss possible applications of our knowledge on basic glycobiology to the development of medicine and biomarkers for cancer therapy.
\end{abstract}

Keywords: cancer; fucose; GlcNAc; N-Glycan; glycosylation; glycosyltransferase

\section{Introduction}

Protein glycosylation, the most abundant post-translational modification, is deeply involved in cellular and organ homeostasis [1]. The cellular glycosylation machinery is often affected by the development of diseases including cancer, leading to the emergence of disease-specific changes in the glycome [2-4]. These glycan changes are not only functionally involved in disease processes, but can also be exploited to distinguish specific diseases as biomarkers. However, regarding cancer biomarkers and therapy, only a few glycan-targeted or glycoform-specific markers are currently in clinical use [2]. To clinically apply basic knowledge on glycobiology to cancer therapy, there is a need for a deeper understanding of the roles of glycans in cancer and their therapeutic potential.

$\mathrm{N}$-glycan, the main subject of this review is one of the two major classes of protein glycosylation (the other is $O$-glycan) and occurs at the Asn-X-Ser/Thr sequon ( $X$ is any amino acid except Pro) [5]. In mammals, after the first en bloc transfer of $\mathrm{N}$-glycan composed of 14 saccharides to a nascent protein in endoplasmic reticulum (ER) [5], it is processed into a mature form by undergoing several trimming and transfer reactions by glycosidases and glycosyltransferases in the Golgi apparatus. To date, 200 glycosyltransferase genes have been cloned, and by cooperating and sometimes competing with each other, the enzymes coded by these genes produce complex $N$-glycan structures on target glycoproteins in cells.

One of the unique features of $N$-glycan structures is the large number of potential branches. All mammalian N-glycans have the common core pentasaccharide [Man $\alpha 1-6$ (Man $\alpha 1-3)$ Man $\beta 1$ 4GlcNAc $\beta 1-4 G l c N A c-A s n]$ and multiple branches are formed on this core structure by the actions of several GlcNAc transferases (GnTs) and a fucose transferase, Fut8 (Figure 1) [6]. As in other 
types of glycosylation, $N$-glycan structures including branches are often altered in cancer cells by several mechanisms.

(a)

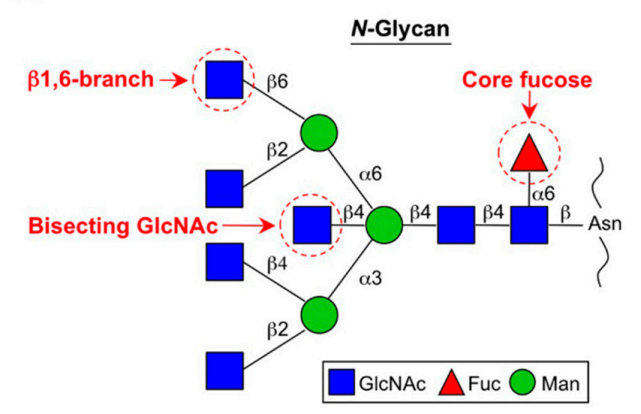

(b)

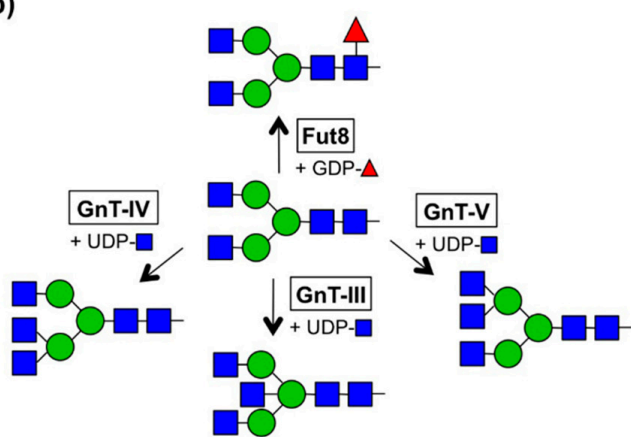

Figure 1. Schematic diagram of $N$-glycan branches and enzymes responsible for their synthesis. (a) Structure of $N$-glycan branches; (b) Specific enzymes responsible for the biosynthesis of $N$-glycan branches.

In this review, we particularly focus on $N$-glycan branches. We first describe the cancer-related changes in the expression of glycosyltransferases responsible for the synthesis of $N$-glycan branches and their functional outcomes. Next, we focus on the mechanisms by which these branches are aberrantly synthesized in cancer by genetic, epigenetic and metabolic mechanisms. Finally, we describe potential clinical applications of these $N$-glycan branches to cancer therapy and diagnosis.

\section{Enzymes for Branch Synthesis and Their Involvement in Cancer}

\subsection{GnT-III (MGAT3)}

GnT-III catalyzes the transfer of a GlcNAc residue to the $\beta$-mannose via the $\beta 1,4$-linkage to make a so-called "bisecting GlcNAc" structure (Figure 1) [7]. Bisecting GlcNAc has unique features that differ from those of other GlcNAc branches [8]. First, bisecting GlcNAc is not or barely elongated, whereas other GlcNAc branches in N-glycan are further decorated with Gal, Sia, Fuc and others (Figure 2). The second feature of bisecting GlcNAc is its negative impact on the activities of other glycosyltransferases. The enzymes responsible for producing other N-glycan branches (e.g., GnT-IV and (GnT-V) are often inhibited almost completely by the presence of a bisecting GlcNAc residue in $N$-glycan $[5,9,10]$. This unique feature gives rise to a complex situation regarding glycan structure because the upregulation of GnT-III could affect the formation of other $N$-glycan structures as well as an increase in bisecting GlcNAc. Therefore we have to bear in mind that up and downregulation of GnT-III protein could change the overall $N$-glycan structures of a protein or cell of interest. Recently it was suggested by molecular dynamics simulation and crystallographic studies that the presence of bisecting GlcNAc has a major impact on the conformer selection of glycans and restricts $N$-glycan conformation to a back-fold type as a preferable conformer [11-14]. This effect may explain the molecular basis for several other glycosyltransferases being unable to act on bisected glycans.

The activity of GnT-III was first identified in the early 1980s [15,16]. Subsequently, our group biochemically purified this enzyme from rat kidney and identified its gene and cDNA [17]. It is noteworthy that normal liver and hepatocytes do not or barely express GnT-III, while drug-induced liver cancer tissue and hepatoma cells express it at high levels [18]. In addition, GnT-III (MGAT3) transcripts or its product bisecting GlcNAc are aberrantly upregulated in some other cancer cells including ovarian cancer [19] and leukemia [20], suggesting that bisecting GlcNAc plays certain roles in cancer development and progression.

To examine the role of bisecting GlcNAc in cancer in vivo, we injected B16 melanoma cells overexpressing GnT-III to syngeneic nude mice and analyzed their metastatic potential. We found 
that the GnT-III transfectant showed significantly less metastasis in mouse lung, suggesting that the overproduction of bisecting GlcNAc can suppress cancer metastasis [21]. Furthermore, Pamela Stanley's group revealed that GnT-III (Mgat3)-deficient mice showed increased tumor growth and metastasis in a polyoma middle T (PyMT)-induced breast cancer model [22]. These results suggest that bisecting GlcNAc reduces cancer growth and aggressiveness. Several mechanisms underlying these phenomena have been suggested. First, the overexpression of GnT-III results in the prolonged cell surface retention of E-cadherin, leading to increased cell adhesion [23]. E-cadherin itself was also reported to upregulate the level of GnT-III, thereby forming a positive feedback loop between E-cadherin and GnT-III that promotes cell adhesion [24,25]. Several cell adhesion molecules are also functionally modified with bisecting GlcNAc including cadherins, laminins and integrins [26-29]. In addition, the expression level of bisecting GlcNAc is downregulated during epithelial-messenchymal transition (EMT) and this downregulation is critical for the process of EMT [30,31]. These lines of evidence show that bisecting GlcNAc regulates cancer metastasis by controlling cellular adhesion. Second, the overexpression or knockout of GnT-III might affect the overall synthesis of $N$-glycan as suggested by the enzymatic properties of other GnTs. In particular, as the GnT-V-producing $\beta 1,6$-branch on $N$-glycan promotes cell proliferation and growth, as described below, bisecting GlcNAc may indirectly regulate cancer cell properties by inhibiting other glycosyltransferases including GnT-V. Furthermore, Jianguo Gu's group recently reported that GnT-III overexpression also inhibited $\alpha 2,3$-sialylation [32], although the mechanisms behind this downregulation of $\alpha 2,3$-Sia remain unclear. The suppressive effect of bisecting GlcNAc on tumor metastasis was also shown to be highly dependent on the cellular sialylation status [32], indicating the importance of obtaining an overview of $\mathrm{N}$-glycan structures when we examine the properties of cancer cells.

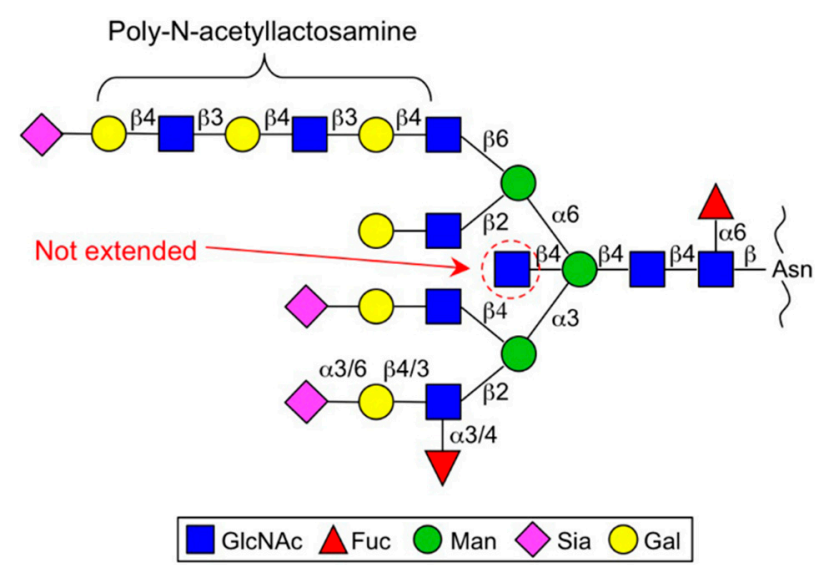

Figure 2. Typical multi-branched N-glycan structure. Bisecting GlcNAc (indicated by a red dashed circle) is not further elongated, whereas other GlcNAc branches are usually elongated by Gal and Sia. The $\beta 1$,6-branch sometimes carries repeating $N$-acetyllactosamine units (polylactosamine).

Surprisingly, GnT-III-deficient mice were found to show retarded tumor progression in a diethylnitrosamine-induced liver cancer model, probably due to reduced hepatocyte proliferation in the mutant mice [33]. Moreover, GnT-III-overexpressing K562 leukemia cells colonized the spleen in nude mice more than control cells did, owing to enhanced evasion from NK cell immunity [34]. These results suggest that GnT-III does not always act as a tumor-suppressing factor, but sometimes works to enhance cancer progression depending on the cancer type and environment around a tumor. Although the reasons for this discrepancy is unclear at present, it suggests that bisecting GlcNAc has a wide range of functions and that different cellular phenotypes may arise from distinct target proteins expressed in each cell type.

We recently found that GnT-III-deficient mice exhibited reduced amyloid- $\beta$ generation in the brain and a great improvement of Alzheimer's disease pathology, with improved performance in short-term 
memory tasks [35,36]. These findings seemed to be caused by the abnormal lysosomal localization of a key protease, $\beta$-secretase (BACE1) in the mutant mice, in contrast to its localization in the early endosomes in wild-type control. Although the precise mechanism by which the endosomal localization of BACE1 is regulated by bisecting GlcNAc is still unclear, this suggests that bisecting GlcNAc modification has the potential to control the intracellular trafficking of target proteins. Large-scale identification of bisecting GlcNAc-containing glycoproteins and their characterization in terms of cellular localization might reveal how bisecting GlcNAc serves as a trafficking tag for its target proteins, which could also be involved in cancer-related cellular events.

\subsection{GnT-V and GnT-IX (GnT-Vb) (MGAT5 and MGAT5B)}

GnT-V catalyzes the transfer of a GlcNAc residue to the $\alpha 1,6$-mannose via the $\beta 1,6$-linkage to make the so-called " $\beta 1,6-G l c N A c$ branch" structure (Figure 1) [37]. This enzyme was first purified by Michael Pierce's group from rat kidney [38,39] and subsequently by our group from a human lung cancer cell line [10]. Many reports have revealed that the levels of MGAT5 mRNA and its enzymatic product $\beta 1,6$-branch are aberrantly upregulated in cancer cells and that this $\beta 1,6$-branch is highly involved in cancer growth and metastasis. The transcriptional mechanisms of oncogenic upregulation (defined hereafter as upregulation by oncogene or its downstream factor) of the GnT-V gene are described below (see Section 3.1 "Genetics").

$\beta 1,6-G l c N A c$ is normally further modified with a $\beta 1,4-G a l$ residue to make an $N$-acetyllactosamine (LacNAc) structure and this LacNAc unit is sometimes repeatedly synthesized by the sequential action of $\beta 3 \mathrm{GnT}$ and $\beta 4 \mathrm{GalT}$ to make a polylactosamine structure, which is considered to act as a high-affinity ligand for galectins (Figure 2) [40]. Galectin-glycan interaction has been proposed to hold the target glycoproteins, such as growth factor receptors at the cell surface and prolong their localization there before endocytosis, which in turn augments growth factor signaling and cell proliferation [41]. Based on this concept, GnT-V is assumed to regulate cell proliferation by controlling the surface retention time of the target proteins. Moreover, the $\beta 1,6$-branch also regulates the function of other cancer-related molecules such as matriptase, tissue inhibitor of metalloproteinase-1 (TIMP-1) and E-cadherin. Matriptase, a serine protease involved in cancer invasion and metastasis, was found to be stabilized and constitutively activated by $\beta 1,6$-branch modification, probably contributing to the enhanced invasiveness of gastric cancer cells [42,43]. Specific $N$-glycosylation sites of E- and $\mathrm{N}$-cadherin are also the target sites for GnT-V action, leading to the increased cell migratory/invasive phenotypes of various cancer cells $[44,45]$. As described above, GnT-V action is inhibited by the presence of bisecting GlcNAc. Therefore, regulation of the functions of these target proteins by GnT-V might compete with that by GnT-III in cancer [46]. Intriguingly, GnT-V itself has a unique basic motif like vascular endothelial growth factor (VEGF) and plays a role in angiogenesis [47]; this function was shown to occur irrespective of its catalytic activity. It is well known that glycosyltransferases including GnT-V are secreted and present in body fluids in a soluble form $[48,49]$ and recent reports have demonstrated that Signal peptide peptidase-like 3 (SPPL3) is a major protease responsible for GnT-V secretion (as described below) [50,51]. Considering the fact that angiogenesis is a critical step for cancer progression, the nonenzymatic angiogenic function of GnT-V could also promote tumor progression in vivo.

GnT-V (Mgat5)-null mice appeared normal but exhibited reduced tumor growth and progression in a PyMT-induced mammary tumor model [52], showing that the $\beta 1,6$-branch plays key roles in tumor progression in vivo. GnT-V-null mice also showed a delay of tumor onset and a reduction of tumor-initiating cells in HER-2/neu-induced mammary tumors [53]. Conversely, the overexpression of GnT-V in normal mammary epithelial cells (MCF-10A) resulted in an increase in cell proliferation and abnormal morphogenesis in $3 \mathrm{D}$ culture, an early characteristic of mammary neoplastic transformation [53]. Furthermore, MGAT5 transcripts and/or their products, $\beta 1,6$-branch, are often upregulated in many types of cancer, such as gastric [54], esophageal [55], colon [56] and liver cancers [57]. The increased expression of $\beta 1,6$-branch was also shown to be correlated with the 
poor prognosis of breast cancer [58]. This accumulating evidence strongly supports the notion that GnT-V plays pivotal roles in cancer onset, growth and metastasis, and is a promising drug target for cancer therapy.

In humans, a cDNA homologous to MGAT5 that encodes the enzyme GnT-IX(Vb) named MGAT5B, was cloned independently by Michael Pierce's group and our group [59,60]. The GnT-IX enzyme shows the same $N$-glycan branching activity as GnT-V but the $\mathrm{K}_{\mathrm{m}}$ value for $N$-glycan substrate is quite high [61]. Instead, this enzyme showed efficient transfer activity toward $O$-mannose glycan with high affinity [62] suggesting that GnT-IX has intrinsic functions that differ from those of GnT-V and acts as a branching enzyme for O-mannose glycans (Figure 3) [63]. This assumption was supported by the unique and exclusive expression of GnT-IX mRNA in the brain [64,65]. In addition, mass-spectrometry (MS) analyses of $\mathrm{N}$-glycans and $\mathrm{O}$-mannose glycans from GnT-V (Mgat5)- and GnT-IX (Mgat5b)-null mouse brains actually revealed that GnT-V and GnT-IX predominantly synthesize $\beta 1$,6-branch in $N$ and $\mathrm{O}$-mannose glycans respectively, although it remains a possibility that GnT-V weakly acts on $\mathrm{O}$-mannose glycans. Interestingly, GnT-IX-null mice exhibited improved remyelination in the brain after cuprizone-induced demyelination [66]. It has been proposed that this phenotype is caused by the attenuation of reactive astrocytes in the mutant mice after injury, and a potential target glycoprotein for this phenomenon, which was modified by GnT-IX, is receptor-type protein phosphatase-zeta (PTPRZ). Increased dimerization and reduced phosphatase activity of PTPRZ were also observed after GnT-IX overexpression in neuroblastoma cells, which resulted in decreased cell adhesion and increased migration [67], suggesting that GnT-IX plays some roles in the regulation of cell adhesion. Notably, $O$-mannose glycans were also shown to be attached to cadherins and to regulate cell adhesive property $[68,69]$. In addition, because defects in the synthesis of $O$-mannose glycans cause severe genetic muscular disorders (referred to as $\alpha$-dystroglycanopathies) [70,71], the biosynthetic pathway for $O$-mannose glycans has received a lot of attention and is an actively studied topic in the field of glycobiology (Figure 3). Regarding cancer, $M G A T 5 B$ was reported to be highly expressed in neuroblastoma cells [72]. It was also reported that $M G A T 5 B$ was identified as a highly upregulated gene in human prostate cancer cells upon metastasis in a mouse xenograft model [73]. In addition, MGAT5B seems to be aberrantly upregulated in various non-brain tumors by epigenetic mechanisms [74]. These results suggest that GnT-IX is involved in cancer progression but its detailed roles in cancer still remain to be elucidated.

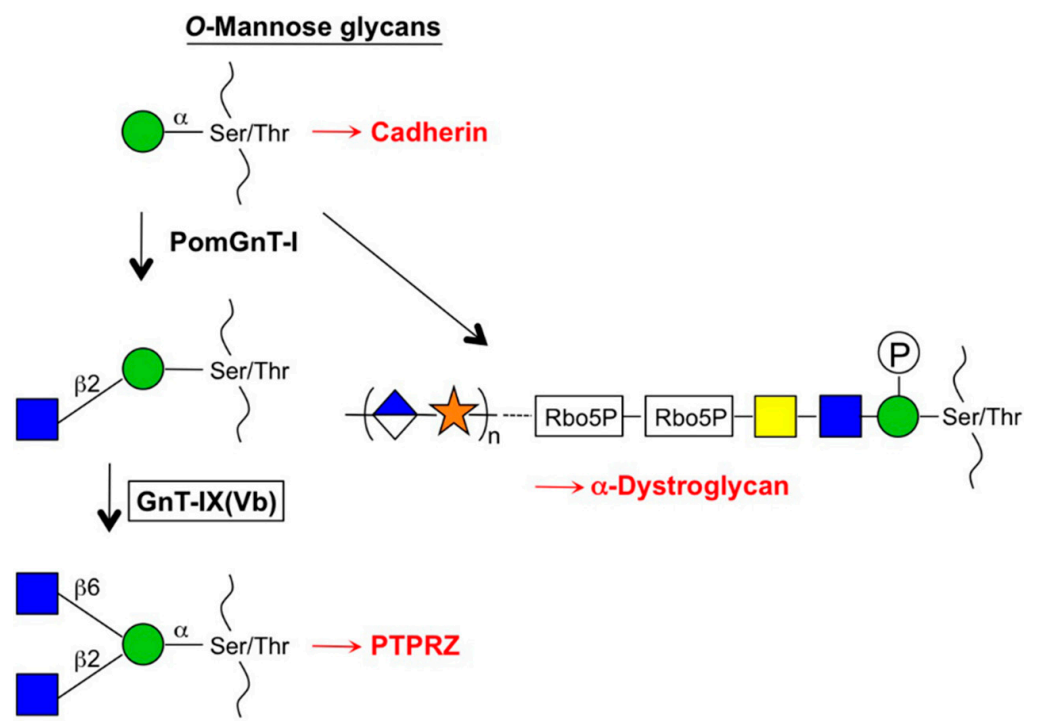

Figure 3. Branch formation in O-mannose glycans. GnT-IX acts on an O-mannose glycan after the action of PomGnT-I. Branched O-mannose glycan is expressed on a phosphatase, PTPRZ, and regulates remyelination in the brain. Phosphorylated and elongated $O$-mannose glycan is attached to $\alpha$-dystroglycan, which is essential for muscle functions. 


\subsection{GnT-IVs (MGAT4A-C)}

GnT-IV catalyzes the transfer of a GlcNAc residue to $\alpha 1,3$-mannose via the $\beta 1,4$-linkage (Figure 1) [75]. This enzyme was purified from bovine small intestine [76] and then its cDNA was subsequently cloned [77]. GnT-IV has three isoforms designated GnT-IVa-c (MGAT4A-C). No enzymatic activity has yet been confirmed for GnT-IVc but in GnT-IVa- and -IVb double-null mice, GnT-IV activity was completely abolished in all tissues tested [78]. We therefore now only focus on these two enzymes. GnT-IVa is distributed in limited tissues, with high expression in the pancreas and intestines, while GnT-IVb is ubiquitously expressed throughout the body. The GnT-IVa isoform displays higher affinity toward both donor and acceptor substrates than GnT-IVb [79], suggesting that GnT-IVa is the dominant GnT-IV enzyme in the tissue where it is expressed. In GnT-IVb (Mgat4b)-null mice, compensative upregulation of the Mgat4a gene was observed in various tissues [78], which explains the very mild phenotypes in GnT-IVb-null mice. Regarding its function, GnT-IVa is well known to be involved in insulin secretion and glucose metabolism in the pancreas, as described below [80].

GnT-IVs were also reported to be involved in cancer but the detailed functions in cancer cells are poorly understood. In some cancer cells, GnT-IVa or GnT-IVb is highly dysregulated including in choriocarcinoma [81], pancreatic cancer [82] and hepatocarcinoma [83] and it has generally been suggested that the product glycan of GnT-IV promotes invasion and metastasis. However, further studies are needed to clarify the functional roles of GnT-IVs and their product glycans in cancer progression.

GnT-IVa is highly expressed in the pancreas and its involvement in type 2 diabetes has been well studied. GnT-IVa-deficient mice were found to exhibit hyperglycemia, reduced insulin levels, and abnormal glucose tolerance [80]. This was found to be caused by the dysfunction of a key glucose transporter, GLUT2. N-glycans of GLUT2 were shown to be modified by GnT-IVa and increased galactosylation on this branch is critical for the binding to galectin and the cell surface retention of GLUT2. In GnT-IVa-null pancreatic $\beta$ cells, GLUT2 was internalized and functionally impaired. Furthermore, a high-fat diet, an important causative factor of insulin resistance, downregulated GnT-IVa expression in the pancreas due to abnormal export of the key transcription factors forkhead box protein A2 (FOXA2) and hepatocyte nuclear factor 1-alpha (HNF1A) from the nuclei [84]. In addition, human type 2 diabetic patients showed the decreased expression of GnT-IVa. These findings clearly show that the GnT-IVa enzyme is critically involved in glucose metabolism and the onset of diabetes. Based on these studies, GnT-IV is considered to provide its target proteins with galectin ligands, similarly to GnT-V. Considering that both galectin [85] and GnT-V (discussed above) are involved in cancer progression, cell-proliferating and invasive effects on cancer cells are also suggested for GnT-IV, similarly to GnT-V. Future studies should reveal how GnT-IVa and -IVb regulate cancer development and metastasis.

\subsection{Fut8 (FUT8)}

Fut8 catalyzes the transfer of a fucose (Fuc) residue to the innermost GlcNAc residue via the $\alpha 1,6$-linkage to make the so-called "core fucose" structure (Figure 1) [86]. This structure is abundant in $\mathrm{N}$-glycans and plays critical roles in numerous physiological and pathological processes, including cancer development and therapeutics [87].

This enzyme was first identified by Harry Schachter's group in the 1980s [88]; our group subsequently purified it from a human gastric cancer cell line and porcine brain and cloned their cDNAs [89,90]. Fut8 is widely expressed in various mammalian tissues, except for liver [91] and like GnT-III, it is also aberrantly upregulated during hepatocarcinogenesis [92]. Moreover, the aberrant upregulation of FUT8 in non-small-cell lung cancer was reported to be correlated with the poor clinical outcomes $[93,94]$, suggesting the involvement of Fut8 in cancer development and its potential as biomarker. 
As expected by the widespread expression and abundance of core fucose, Fut8 (Fut8)-null mice show multiple phenotypes including semilethality [95], the development of emphysema [95,96], dysfunction in the brain $[97,98]$ and impaired immunity $[99,100]$. Some of these phenotypes are attributed to the dysfunction of growth factor receptors, such as epidermal growth factor (EGF) and transforming growth factor-beta (TGF $\beta$ ) [6,101]. In addition, several reports have revealed that core fucose is required for growth factor-dependent cell proliferation in disease models such as lung cancer [102] and liver regeneration [103]. These findings strongly suggest that Fut8 promotes cancer growth. In fact a recent report demonstrated that Fut8-null mice exhibited reduced cancer growth in a chemical-induced hepatoma model [104]. Moreover, Fut8 or core fucose is aberrantly upregulated in several types of cancer in addition to hepatoma and lung cancer, such as breast [105] and prostate cancers [106,107].

Core fucosylation has already been clinically applied as a biomarker for the detection of cancer. Since Fut8 is aberrantly elevated in hepatocellular carcinoma compared with nearly no expression in normal liver, we can assume that liver-derived core fucosylated proteins in serum would be utilized for the diagnosis of liver cancer. In fact, fucosylated alpha-fetoprotein (AFP), AFP-L3, has been developed as a biomarker and approved for the early detection of liver cancer [108], being the most successful glyco-related cancer biomarker to date [2,109]. AFP itself is an oncofetal protein and was first found to be a marker of hepatoma [110]. However, the serum AFP level is also increased in other nonhepatoma diseases such as liver cirrhosis and acute and chronic hepatitis, which makes it difficult to diagnose primary hepatoma at an early stage using AFP alone. AFP glycoforms can be separated by using a fucose-specific plant lectin, Lens culinaris agglutinin (LCA), to give L1, L2 and L3 fractions and AFP-L3 is mostly expressed in the sera of primary hepatoma patients, but not in cases of liver cirrhosis. Based on this finding, AFP-L3 was approved by the US Food and Drug Administration (FDA) as a biomarker for the early detection of hepatocellular carcinoma. Our glycomic analysis revealed that L3 showed the highest level of core fucose among the three fractions [111]. Furthermore, fucosylated haptoglobin was also identified as a marker for various types of cancer [112,113]. Our site-specific glycomic analysis revealed that both core fucose and Lewis types of fucose that is synthesized by other Futs expressed on haptoglobin, are increased in various cancers [114]. Again, these results highlight the importance of core fucose for understanding the roles of glycans in liver cancer and their therapeutic applications.

The involvement of core fucose in antibody cancer therapy has also been reported. Antibodydependent cellular cytotoxicity (ADCC) has a central role in cancer therapy using antibodies [115]. The removal of core fucose from IgG-Fc $N$-glycans was found to enchance ADCC activity by approximately 50-fold [116,117]. Sialylation and bisecting GlcNAcylation of IgG-Fc have also been shown to have effects on its efficacy [118] and $N$-glycan decoration is also known to be critical for the half-life in sera and the antigenicity of biopharmaceuticals [119]. These results underscore the importance of $\mathrm{N}$-glycan branching, especially core fucosylation, for effective and safe therapy using biopharmaceuticals.

\section{Regulation of $N$-glycan Branches in Cancer by Several Pathways}

\subsection{Genetics}

Although the specific factors involved in transcriptional regulation of the genes encoding $N$-glycan branching enzymes are not well understood, some transcription factors were found to be critical for transcriptional activation of these genes in cancer cells. Oncogenic upregulation of the GnT-V gene (MGAT5) is the best studied among the branching enzymes described above. It was found that the Src-Raf-Ets2 pathway is involved in GnT-V activation during the transformation of BHK cells by Rous sarcoma virus [120]. Similarly, the same group reported that the Her-2/neu oncogene upregulates GnT-V in 3T3 fibroblasts via the Ras-Raf-Ets pathway [121]. Our group independently found that the Ets-1 oncogenic transcription factor directly transactivates the MGAT5 promoter in human bile duct carcinoma cells [122] and that the Ets-1 levels were highly correlated with the levels of GnT-V 
expression in various cancer cell lines [123]. These reports suggest that the oncogenic Ets pathway is directly involved in GnT-V transactivation.

Other transcription factors responsible for the regulation of $\mathrm{N}$-glycan branching genes have also been reported, although their roles in oncogenesis are still not fully understood. For example, GnT-IVa transcription is highly activated by the liver- and pancreas-specific transcription factors HNF1A and FOXA2 [84]. In contrast to GnT-IVa, a GWAS study identified HNF1A as a negative regulator of FUT8 transcription [124], which may explain why FUT8 is barely expressed in the liver. The tissue-specific expression of GnT-IX is regulated by the specific transcription factors NeuroD1 and CCCTC-binding factor (CTCF) $[64,65]$ but their contributions to the cancer-related upregulation of GnT-IX are still unclear. Intriguingly, cell density on a culture dish affects the transcription of the GnT-III gene (MGAT3) and high-cell-density conditions were found to induce MGAT3 transcription. In addition, E-cadherin- $\alpha$-catenin complex was shown to be involved in this process [125]. Meanwhile, Wnt/ $\beta$-catenin signaling was also reported to regulate GnT-III expression $[126,127]$. Identification of the specific transcription factors for the oncogenic transcription of $N$-glycan branching genes is an interesting topic for future research.

\subsection{Epigenetics}

When considering the topic of genetic regulation of the $\mathrm{N}$-glycan branching enzymes in cancer, epigenetic factors should not be overlooked. Epigenetics involves the structural adaptation of chromosomal regions beyond changes in DNA sequence and numerous cancerous changes in gene transcription and genome organization have been shown to be highly dependent on epigenetic mechanisms [128,129]. Structural adaptations of chromosomal regions are mediated by DNA modifications (mainly methylation in $\mathrm{CPG}$ ), histone modifications, noncoding RNA including micro-RNA (miRNA) and ATP-dependent chromatin remodeling [128]. We here focus on how N-glycan branching genes are epigenetically regulated in cancer, particularly by DNA methylation, histone modifications and miRNAs.

DNA methylation often occurs at $\mathrm{CpG}$ sites and methylation of a CpG cluster at an upstream promoter region (CpG island) is well known to silence gene transcription [130]. The methylation of a CpG island allows methyl-CpG-binding proteins to bind and recruit other chromatin silencing proteins such as histone deacetylases (HDACs). DNA methylation used to be considered stable but the recent identification of ten-eleven translocation (TET) family proteins as methylated CpG conversion enzymes has required re-evaluation of this concept, leading to the current view that DNA methylation is more dynamic [131]. Some of the $N$-glycan branching genes were also found to be silenced by DNA methylation or activated by DNA hypomethylation. For example, DNA hypomethylation of the MGAT3 promoter is involved in its upregulation in ovarian cancer cells [132]. MGAT3 gene is also regulated by DNA methylation in other types of cancer and also during the process of EMT [31,74]; in addition, GnT-IV genes (MGAT4A and $4 B$ ) were reported to be regulated by DNA methylation in pancreatic cancer [82]. Effects of altered DNA methylation on global $N$-glycan profiles including core fucose and $\beta 1,6$-branch were also studied in some cancer cells [133]. These results highlight the importance of epigenetic DNA methylation for understanding cancerous changes in $\mathrm{N}$-glycan branching.

Histone tails are usually subjected to various forms of modifications (e.g., methylation, acetylation, O-GlcNAcylation, and ubiquitination). These histone modifications are now considered to be pivotal for the epigenetic regulation of gene transcription [134]. The mechanisms by which the $\mathrm{N}$-glycan branching genes are regulated by histone modifications in cancer cells are less understood than other epigenetic mechanisms [135]. GnT-IX (MGAT5B) is the best studied gene regarding its epigenetic mechanism [64,65]. Histones around Mgat5b transcription start sites are modified in a neural-cell-specific manner, which is subsequently required for the efficient binding of the specific transcription activators NeuroD1 and CTCF [64,65]. Such tissue-specific chromatin regulation of $M g a t 5 b$ is mediated by specific chromatin modifiers such as HDAC11, O-GlcNAc transferase (OGT) 
and TET3 [64]. In future studies, it would be interesting to investigate the as-yet-unknown mechanisms involving histone modifications for the other $\mathrm{N}$-glycan branching genes in cancer cells.

An increasing number of reports on miRNA-dependent mechanisms of glycan expression have been published. miRNAs are short noncoding RNAs that negatively regulate gene expression by mRNA degradation or translation blockade [136]. As expected by their abundance (over 1,000 miRNAs have been identified in humans), many glyco-genes are also direct and indirect targets of miRNAs. FUT8 transcription has been reported to be regulated by several miRNAs in cancer cells. For example, miRNA-198 shows a negative correlation with poor clinical outcomes in colorectal cancer and FUT8 was found to be a direct target of this miRNA [137]. In addition, the miRNA-198-mediated suppression of FUT8 inhibited the proliferation and invasion of colorectal cancer cells. In hepatoma cells, FUT8 was also found to be suppressed by miR-122 and miR-34a [138]. Recently, the GnT-IVa gene (MGAT4A) was shown to be silenced by miR-424 in epithelial cells, which is involved in cell cycle progression [139]. The same group has also reported several interesting findings regarding the relationships between glyco-genes and miRNAs, such as comparison of the levels of glycogenes and miRNAs in various cancer cells and prediction of miRNA binding sites in glycogene 3'-UTRs [140-142].

\subsection{Nucleotide Sugar Metabolism}

Nucleotide sugars (e.g., UDP-GlcNAc and GDP-Fuc), the donor substrates for glycosylation reactions, are essential nongenetic factors for glycan expression. Most $\mathrm{N}$-glycan branching enzymes utilize UDP-GlcNAc, which is the end-product of the hexosamine pathway. Because this pathway integrates the metabolism of glucose, glutamine, acetyl-CoA and UTP [143], cellular nutrient conditions are assumed to have a major impact on it. The $\mathrm{K}_{\mathrm{m}}$ values for UDP-GlcNAc are highly variable among GnTs with GnT-V possessing the highest [144], meaning that the synthesis of $N$-glycan branching can be influenced by nutrient flux. In addition, importantly, it is well known that sugar and energy metabolism is often altered in cancer cells compared with that in normal cells [145]. We previously developed methods for the simultaneous quantification of various nucleotide sugars by using ion-pair reverse-phase HPLC and found significant differences in the levels of nucleotide sugars between breast and pancreatic cancer cells [146]. Our mass isotopomer analysis further supported the notion that UDP-GlcNAc metabolism is regulated in a cell-type-specific manner [147]. These techniques are helpful to further understand how nucleotide sugar metabolism is involved in cancerous changes in $N$-glycan branching.

We also identified a unique regulatory mechanism of nucleotide sugars involving a phosphodiesterase. We biochemically purified and identified ectonucleotide pyrophosphatase/ phosphodiesterase 3 (ENPP3) as an endogenous inhibitor of the GnT-IX enzyme [148]. Subsequent characterization revealed that ENPP3 hydrolyzes UDP-GlcNAc and generates UMP, a potent inhibitor of the GnT-IX reaction. Furthermore, knockdown of ENPP3 resulted in a change in the global cellular glycan profile, suggesting that ENPP3 globally regulates cellular glycosylation. Similar mechanisms probably regulate nucleotide sugars in normal and cancer cells, leading to indirect regulation of the cellular glycosylation system.

\subsection{Subcellular Localization and the Cleavage of Branching Enzymes}

The cell biological properties of glycosyltransferases such as their subcellular localization and cleavage/shedding, also critically regulates their cellular activity. The $\mathrm{N}$-glycan branching enzymes are considered to be localized in the Golgi apparatus like many other glycosyltransferases. Although no reports have yet been published showing that their subcellular localization is altered in cancer cells, cancer-specific changes in the localization of glycosyltransferases have been shown to have a significant impact on the cellular glycosylation system $[149,150]$. Notably, our group reported that caveolin-1 appeared to regulate the localization and cellular activity of GnT-III in hepatoma cells [151], leading to the possibility of bisecting GlcNAc being involved in caveolin-1-related cancer phenotypes [152]. 
Recently, a Golgi-resident protease, SPPL3, was found to be responsible for the physiological shedding of various glycosyltransferases including GnT-V [50,51]. The overexpression of SPPL3 was found to suppress cellular glycosylation, especially the late-stage maturation of $\mathrm{N}$-glycosylation and SPPL3-deficient cells conversely showed phenotypes of hyper-glycosylation. These SPPL3-dependent changes in glycosylation were partially attributed to the change in GnT-V activity. These results clearly showed that the cleavage and shedding of GnT-V by SPPL3 suppress GnT-V activity. Although the consequences of shedding of other glycosyltransferases by SPPL3 are still unclear, it is strongly expected that SPPL3 (down) regulates multiple enzymes involved in the cellular glycosylation system. It would also be interesting to determine the relationships between the SPPL3-mediated shedding of $\mathrm{N}$-glycan branching enzymes and cancer biology in future studies.

The multiple mechanisms regulating $\mathrm{N}$-glycan branching in cancer cells described here are summarized in Figure 4 and the references for the upregulation of the $\mathrm{N}$-glycan branching enzymes in various cancer types are listed in Table 1. Notably, other mechanisms are also involved in regulation of $\mathrm{N}$-glycan branching such as trafficking rate of acceptor proteins, regulation of nucleotide sugar transporters, solvent accessibility at the sites to be modified [153] and crosstalk to other posttranslational modifications. In fact, multiple $\mathrm{N}$-glycan changes were observed in colorectal cancer in a stage-specific manner and $\mathrm{N}$-glycan branching was found to also be regulated by cellular EGFR-status [154]. Multiple factors should be considered for better understanding how N-glycan branching is dysregulated in cancer.

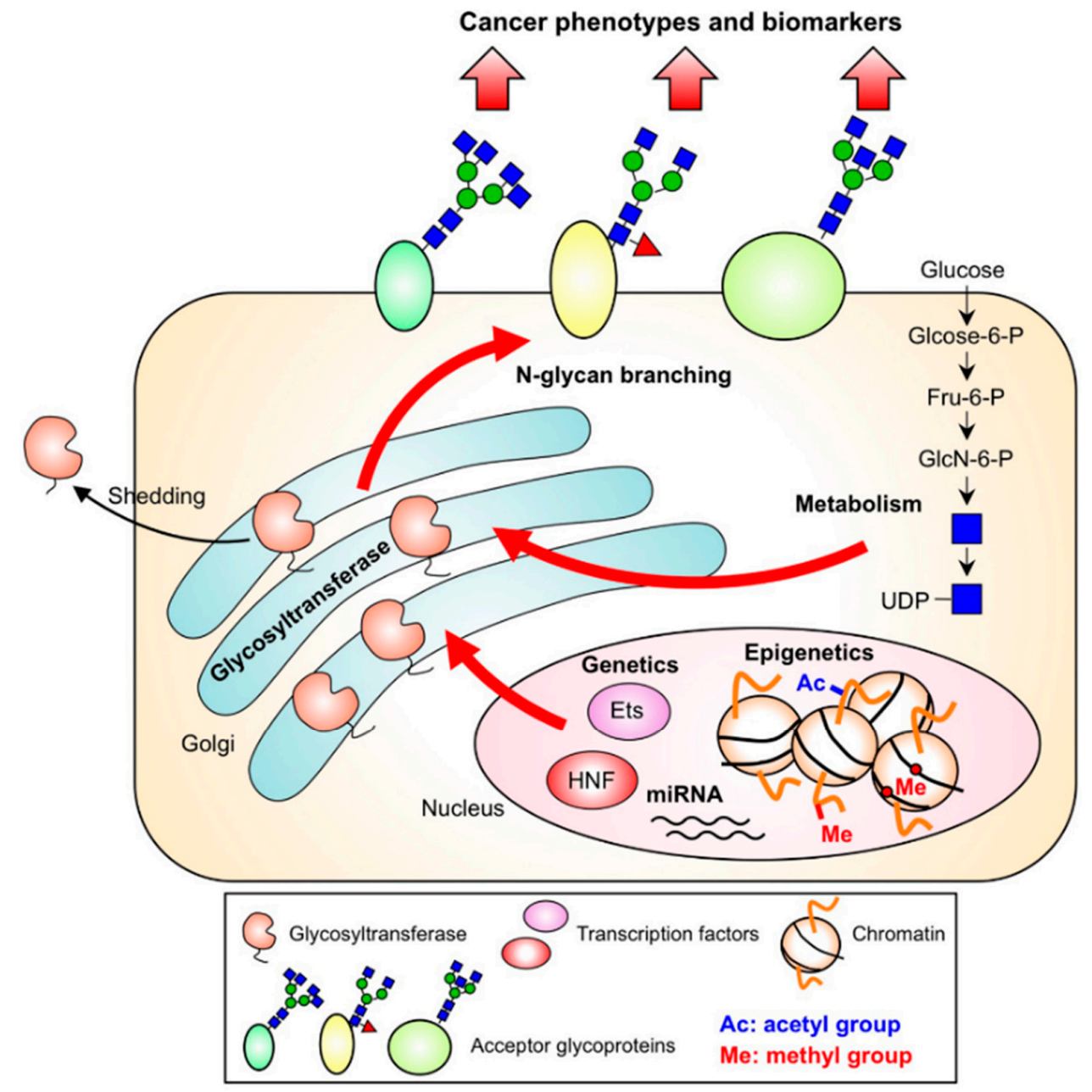

Figure 4. Overview of the mechanisms regulating the synthesis of $N$-glycan branches in cancer cells. 
Table 1. Branching enzymes and their involvement in cancer.

\begin{tabular}{|c|c|c|c|c|}
\hline Enzyme & Gene & Glycan & Dysregulation in cancer & Functional output in cancer \\
\hline GnT-III & MGAT3 & Bisecting GlcNAc & $\begin{array}{l}\text { Hepatoma [18], ovarian } \\
\text { cancer [19], leukemia [20] }\end{array}$ & $\begin{array}{c}\text { Suppression of } \\
\text { metastasis [21], decrease in } \\
\text { tumor growth [22], } \\
\text { suppression of EMT }[30,31] \\
\text { tumor growth }[33,34]\end{array}$ \\
\hline GnT-IVa-c & $M G A T 4 A-C$ & $\beta 1,4$-branch & $\begin{array}{c}\text { Choriocarcinoma [81], } \\
\text { pancreatic cancer [82], } \\
\text { hepatoma [83] }\end{array}$ & Invasion [81], metastasis [83] \\
\hline GnT-V & MGAT5 & $\begin{array}{l}\beta 1,6 \text {-branch on } \\
\alpha 1,6 \text {-mannose }\end{array}$ & $\begin{array}{l}\text { Gastric [54], esophageal [55], } \\
\text { colon [56], liver [57] cancers }\end{array}$ & $\begin{array}{l}\text { Angiogenesis [47], tumor } \\
\text { growth }[52,53]\end{array}$ \\
\hline GnT-Vb (IX) & MGAT5b & $\begin{array}{l}\beta 1,6 \text {-branch on } \\
\text { O-mannose }\end{array}$ & $\begin{array}{l}\text { Neuroblastoma [72], } \\
\text { prostate cancer [73] }\end{array}$ & $\begin{array}{c}\text { Decreased adhesion, } \\
\text { increased migration [67] }\end{array}$ \\
\hline Fut8 & FUT8 & Core fucose & $\begin{array}{c}\text { Hepatoma [92], lung [93,94], } \\
\text { breast [105], } \\
\text { prostate [106,107] cancers }\end{array}$ & $\begin{array}{c}\text { Tumor } \\
\text { growth }[93,94,102,104], \\
\text { tumor biomarker [108], } \\
\text { antibody therapy } \\
\text { (ADCC) }[116,117]\end{array}$ \\
\hline
\end{tabular}

\section{Potential Clinical Applications as Drug Targets}

As described above, the changes in $\mathrm{N}$-glycan branching are expected to be good targets for cancer therapy, including as biomarkers for early detection and anticancer drugs. To develop glyco-related biomarkers, antibodies or lectins are currently used for glycan detection. Unfortunately however, the low antigenicity of glycans and the low affinities of lectins often make it difficult to detect target glycans with high sensitivity and specificity. Technical advances will be needed to detect target glycans for clinical applications. Glycomic and glycoproteomic techniques using mass-spectrometry have been greatly improved $[155,156]$. Furthermore, a click chemistry approach using a sugar analog is one unique and promising strategy for this $[157,158]$. This approach can specifically label and tag target sugars in cells by using alkynyl- or azide-sugars as bioorthogonal chemical reporters. Although this metabolic approach is highly specific and is very promising for the selective detection of a target sugar, there are still some shortcomings of using non-natural sugars, such as cytotoxicity and low efficiency of labeling [159]. In addition, because a sugar analog is broadly incorporated into various types of glycan, we are currently unable to label a specific branch or specific part of glycans. The development of a new type of sugar analog is thus required to apply this click strategy to clinical research, such as for biomarker discovery.

Chemical inhibitors or activators of the $\mathrm{N}$-glycan branching enzymes are considered to be useful as potential anticancer drugs, as well as tools for basic research. In particular, GnT-V inhibitors would be of great interest regarding the development of anticancer drugs. To date, no specific and potent inhibitors of these enzymes have been established, although chemically designed substrate analogs were shown to have inhibitory activities toward GnT-V or GnT-III [160,161]. The current lack of data on the tertiary structure of branching enzymes, except for Fut8 [162], makes it difficult to design in silico chemical modulators of their activity. An effective assay system to measure their activity for high-throughput screening also remains to be established. Solving their crystal structures and identifying their inhibitors/activators are difficult but meaningful challenges for future research.

\section{Conclusions}

In this review, we have provided an overview of how $\mathrm{N}$-glycan branches are expressed and function in cancer cells. We know that the synthesis of $\mathrm{N}$-glycan branches in cancer cells is regulated by multiple mechanisms encompassing genetics, epigenetics, the localization and shedding of the branching enzymes and the levels of donor substrates. Although our knowledge on this field has been increasing, there are still obstacles to its clinical application. To overcome these obstacles, technical 
breakthroughs for next-generation glycobiology research are needed, such as highly sensitive and protein-selective detection of target glycans and the development of novel chemical tools. A deeper understanding of the functions and properties of the branching enzymes is also required, such as their precise subcellular localization, mechanisms of protein-selective modifications and the nongenetic regulation of their expression. Future studies on these issues could eventually lead to the development of new strategies to combat cancer.

Acknowledgments: This work was partially supported by RIKEN (the Systems Glycobiology Research project to Naoyuki Taniguchi), by The Japan Society for the Promotion of Science (Grant-in-Aid for Challenging Exploratory Research to Naoyuki Taniguchi [grant number 15K14481] and Yasuhiko Kizuka [grant number 26670148], Grant-in-Aid for Scientific Research (B) to Naoyuki Taniguchi [grant number 15H04700], and Grant-in-Aid for Scientific Research on Innovative Areas to Yasuhiko Kizuka [grant number 26110723]), and by Takeda Science Foundation.

Author Contributions: Yasuhiko Kizuka and Naoyuki Taniguchi have planned and wrote the article.

Conflicts of Interest: The authors declare no conflict of interest.

\section{Abbreviations}

The following abbreviations are used in this manuscript:

$\begin{array}{ll}\text { Fuc } & \text { Fucose } \\ \text { Fut } & \text { Fucosyltransferase } \\ \text { Gal } & \text { Galactose } \\ \text { GlcNAc } & \text { N-Acetylglucosamine } \\ \text { GnT } & N \text {-Acetylglucosaminyltransferase } \\ \text { miRNA } & \text { microRNA } \\ \text { Sia } & \text { Sialic acid }\end{array}$

\section{References}

1. Moremen, K.W.; Tiemeyer, M.; Nairn, A.V. Vertebrate protein glycosylation: Diversity, synthesis and function. Nat. Rev. Mol. Cell Biol. 2012, 13, 448-462. [CrossRef]

2. Pinho, S.S.; Reis, C.A. Glycosylation in cancer: Mechanisms and clinical implications. Nat. Rev. Cancer 2015, 15, 540-555. [CrossRef] [PubMed]

3. Taniguchi, N.; Kizuka, Y. Glycans and cancer: Role of N-glycans in cancer biomarker, progression and metastasis, and therapeutics. Adv. Cancer Res. 2015, 126, 11-51.

4. Hakomori, S. Glycosylation defining cancer malignancy: New wine in an old bottle. Proc. Natl. Acad. Sci. USA 2002, 99, 10231-10233. [CrossRef]

5. Stanley, P.; Schachter, H.; Taniguchi, N. N-glycans. In Essentials of glycobiology, 2nd ed.; Varki, A., Cummings, R.D., Esko, J.D., Freeze, H.H., Stanley, P., Bertozzi, C.R., Hart, G.W., Etzler, M.E., Eds.; Cold Spring Harbor: New York, NY, USA, 2009.

6. Taniguchi, N.; Korekane, H. Branched N-glycans and their implications for cell adhesion, signaling and clinical applications for cancer biomarkers and in therapeutics. BMB Rep. 2011, 44, 772-781. [CrossRef]

7. Ikeda, Y.; Ihara, H.; Tsukamoto, H.; Gu, J.; Taniguchi, N. Mannosyl (beta-1,4-)-glycoprotein beta-1,4-Nacetylglucosaminyltransferase (mgat3); $\beta 1,4-N$-acetylglucosaminyltransferase III (gnt-III, glcnact-III). In Handbook of Glycosyltransferases and Related Genes; Taniguchi, N., Honke, K., Fukuda, M., Narimatsu, H., Yamaguchi, Y., Angata, T., Eds.; Springer Japan: Tokyo, Japan, 2014; pp. 209-222.

8. Zhao, Y.; Sato, Y.; Isaji, T.; Fukuda, T.; Matsumoto, A.; Miyoshi, E.; Gu, J.; Taniguchi, N. Branched N-glycans regulate the biological functions of integrins and cadherins. FEBS J. 2008, 275, 1939-1948. [CrossRef] [PubMed]

9. Schachter, H. Biosynthetic controls that determine the branching and microheterogeneity of protein-bound oligosaccharides. Biochem. Cell Biol. 1986, 64, 163-181. [CrossRef] [PubMed]

10. Gu, J.; Nishikawa, A.; Tsuruoka, N.; Ohno, M.; Yamaguchi, N.; Kangawa, K.; Taniguchi, N. Purification and characterization of udp- $N$-acetylglucosamine: Alpha-6-d-mannoside beta 1-6n-acetylglucosaminyltransferase ( $N$-acetylglucosaminyltransferase v) from a human lung cancer cell line. J. Biochem. 1993, 113, 614-619. [PubMed] 
11. Re, S.; Miyashita, N.; Yamaguchi, Y.; Sugita, Y. Structural diversity and changes in conformational equilibria of biantennary complex-type $N$-glycans in water revealed by replica-exchange molecular dynamics simulation. Biophys. J. 2011, 101, L44-L46. [CrossRef] [PubMed]

12. Nagae, M.; Kanagawa, M.; Morita-Matsumoto, K.; Hanashima, S.; Kizuka, Y.; Taniguchi, N.; Yamaguchi, Y. Atomic visualization of a flipped-back conformation of bisected glycans bound to specific lectins. Sci. Rep. 2016, 6, 22973. [CrossRef] [PubMed]

13. Fujii, S.; Nishiura, T.; Nishikawa, A.; Miura, R.; Taniguchi, N. Structural heterogeneity of sugar chains in immunoglobulin G. Conformation of immunoglobulin g molecule and substrate specificities of glycosyltransferases. J. Biol. Chem. 1990, 265, 6009-6018. [PubMed]

14. Taniguchi, N.; Yoshimura, M.; Miyoshi, E.; Ihara, Y.; Nishikawa, A.; Fujii, S. Remodeling of cell surface glycoproteins by $\mathrm{N}$-acetylglucosaminyltransferase iii gene transfection: Modulation of metastatic potentials and down regulation of hepatitis b virus replication. Glycobiology 1996, 6, 691-694. [CrossRef] [PubMed]

15. Narasimhan, S. Control of glycoprotein synthesis. Udp-glcnac:Glycopeptide beta $4-N$-acetylglucosaminyltransferase iii, an enzyme in hen oviduct which adds glcnac in beta 1-4 linkage to the beta-linked mannose of the trimannosyl core of $N$-glycosyl oligosaccharides. J. Biol. Chem. 1982, 257, 10235-10242. [PubMed]

16. Gleeson, P.A.; Schachter, H. Control of glycoprotein synthesis. J. Biol. Chem. 1983, 258, 6162-6173. [PubMed]

17. Nishikawa, A.; Ihara, Y.; Hatakeyama, M.; Kangawa, K.; Taniguchi, N. Purification, cdna cloning, and expression of udp- $N$-acetylglucosamine: Beta-d-mannoside beta-1,4n-acetylglucosaminyltransferase iii from rat kidney. J. Biol. Chem. 1992, 267, 18199-18204. [PubMed]

18. Miyoshi, E.; Nishikawa, A.; Ihara, Y.; Gu, J.; Sugiyama, T.; Hayashi, N.; Fusamoto, H.; Kamada, T.; Taniguchi, N. N-acetylglucosaminyltransferase III and V messenger rna levels in lec rats during hepatocarcinogenesis. Cancer Res. 1993, 53, 3899-3902. [PubMed]

19. Abbott, K.L.; Nairn, A.V.; Hall, E.M.; Horton, M.B.; McDonald, J.F.; Moremen, K.W.; Dinulescu, D.M.; Pierce, M. Focused glycomic analysis of the $N$-linked glycan biosynthetic pathway in ovarian cancer. Proteomics 2008, 8, 3210-3220. [CrossRef] [PubMed]

20. Yoshimura, M.; Nishikawa, A.; Ihara, Y.; Nishiura, T.; Nakao, H.; Kanayama, Y.; Matuzawa, Y.; Taniguchi, N. High expression of udp- $N$-acetylglucosamine: Beta-d mannoside beta-1,4- $N$-acetylglucosaminyltransferase iii (gnt-iii) in chronic myelogenous leukemia in blast crisis. Int. J. Cancer 1995, 60, 443-449. [CrossRef] [PubMed]

21. Yoshimura, M.; Nishikawa, A.; Ihara, Y.; Taniguchi, S.; Taniguchi, N. Suppression of lung metastasis of b16 mouse melanoma by $\mathrm{N}$-acetylglucosaminyltransferase iii gene transfection. Proc. Natl. Acad. Sci. USA 1995, 92, 8754-8758. [CrossRef] [PubMed]

22. Song, Y.; Aglipay, J.A.; Bernstein, J.D.; Goswami, S.; Stanley, P. The bisecting glcnac on N-glycans inhibits growth factor signaling and retards mammary tumor progression. Cancer Res. 2010, 70, 3361-3371. [CrossRef] [PubMed]

23. Yoshimura, M.; Ihara, Y.; Matsuzawa, Y.; Taniguchi, N. Aberrant glycosylation of e-cadherin enhances cell-cell binding to suppress metastasis. J. Biol. Chem. 1996, 271, 13811-13815. [PubMed]

24. Pinho, S.S.; Reis, C.A.; Paredes, J.; Magalhaes, A.M.; Ferreira, A.C.; Figueiredo, J.; Xiaogang, W.; Carneiro, F.; Gartner, F.; Seruca, R. The role of $N$-acetylglucosaminyltransferase iii and $\mathrm{v}$ in the post-transcriptional modifications of e-cadherin. Hum. Mol. Genet. 2009, 18, 2599-2608. [CrossRef] [PubMed]

25. Iijima, J.; Zhao, Y.; Isaji, T.; Kameyama, A.; Nakaya, S.; Wang, X.; Ihara, H.; Cheng, X.; Nakagawa, T.; Miyoshi, E.; et al. Cell-cell interaction-dependent regulation of $\mathrm{N}$-acetylglucosaminyltransferase iii and the bisected $\mathrm{N}$-glycans in ge11 epithelial cells. Involvement of e-cadherin-mediated cell adhesion. J. Biol. Chem. 2006, 281, 13038-13046. [CrossRef] [PubMed]

26. Isaji, T.; Gu, J.; Nishiuchi, R.; Zhao, Y.; Takahashi, M.; Miyoshi, E.; Honke, K.; Sekiguchi, K.; Taniguchi, N. Introduction of bisecting glcnac into integrin alpha5beta1 reduces ligand binding and down-regulates cell adhesion and cell migration. J. Biol. Chem. 2004, 279, 19747-19754. [CrossRef] [PubMed]

27. Kariya, Y.; Kato, R.; Itoh, S.; Fukuda, T.; Shibukawa, Y.; Sanzen, N.; Sekiguchi, K.; Wada, Y.; Kawasaki, N.; $\mathrm{Gu}, \mathrm{J}$. N-glycosylation of laminin-332 regulates its biological functions. A novel function of the bisecting glcnac. J. Biol. Chem. 2008, 283, 33036-33045. [CrossRef] [PubMed]

28. Kitada, T.; Miyoshi, E.; Noda, K.; Higashiyama, S.; Ihara, H.; Matsuura, N.; Hayashi, N.; Kawata, S.; Matsuzawa, Y.; Taniguchi, N. The addition of bisecting $N$-acetylglucosamine residues to e-cadherin down-regulates the tyrosine phosphorylation of beta-catenin. J. Biol. Chem. 2001, 276, 475-480. [CrossRef] [PubMed] 
29. Pinho, S.S.; Seruca, R.; Gartner, F.; Yamaguchi, Y.; Gu, J.; Taniguchi, N.; Reis, C.A. Modulation of e-cadherin function and dysfunction by N-glycosylation. Cell Mol. Life Sci. 2011, 68, 1011-1020. [CrossRef] [PubMed]

30. Xu, Q.; Isaji, T.; Lu, Y.; Gu, W.; Kondo, M.; Fukuda, T.; Du, Y.; Gu, J. Roles of N-acetylglucosaminyltransferase iii in epithelial-to-mesenchymal transition induced by transforming growth factor beta1 (TGF-beta1) in epithelial cell lines. J. Biol. Chem. 2012, 287, 16563-16574. [CrossRef] [PubMed]

31. Pinho, S.S.; Oliveira, P.; Cabral, J.; Carvalho, S.; Huntsman, D.; Gartner, F.; Seruca, R.; Reis, C.A.; Oliveira, C. Loss and recovery of mgat 3 and GnT-III mediated e-cadherin $N$-glycosylation is a mechanism involved in epithelial-mesenchymal-epithelial transitions. PLoS ONE 2012, 7, e33191. [CrossRef] [PubMed]

32. Lu, J.; Isaji, T.; Im, S.; Fukuda, T.; Kameyama, A.; Gu, J. Expression of N-acetylglucosaminyltransferase iii suppresses alpha2,3 sialylation and its distinctive functions in cell migration are attributed to alpha2,6 sialylation levels. J. Biol. Chem. 2016, 291, 5708-5720. [CrossRef] [PubMed]

33. Yang, X.; Tang, J.; Rogler, C.E.; Stanley, P. Reduced hepatocyte proliferation is the basis of retarded liver tumor progression and liver regeneration in mice lacking $\mathrm{N}$-acetylglucosaminyltransferase III. Cancer Res. 2003, 63, 7753-7759. [PubMed]

34. Yoshimura, M.; Ihara, Y.; Ohnishi, A.; Ijuhin, N.; Nishiura, T.; Kanakura, Y.; Matsuzawa, Y.; Taniguchi, N. Bisecting $N$-acetylglucosamine on $\mathrm{k} 562$ cells suppresses natural killer cytotoxicity and promotes spleen colonization. Cancer Res. 1996, 56, 412-418. [PubMed]

35. Kizuka, Y.; Kitazume, S.; Fujinawa, R.; Saito, T.; Iwata, N.; Saido, T.C.; Nakano, M.; Yamaguchi, Y.; Hashimoto, Y.; Staufenbiel, M.; et al. An aberrant sugar modification of bace1 blocks its lysosomal targeting in Alzheimer's disease. EMBO Mol. Med. 2015, 7, 175-189. [CrossRef] [PubMed]

36. Kizuka, Y.; Nakano, M.; Kitazume, S.; Saito, T.; Saido, T.C.; Taniguchi, N. Bisecting glcnac modification stabilizes bace1 protein under oxidative stress conditions. Biochem. J. 2015, 473, 21-30. [CrossRef] [PubMed]

37. Dennis, J.W.; Taniguchi, N.; Pierce, M. Mannosyl (alpha-1,6-)-glycoprotein beta-1,6-N-acetylglucosaminyltransferase (mgat5). In Handbook of Glycosyltransferases and Related Genes; Taniguchi, N., Honke, K., Fukuda, M., Narimatsu, H., Yamaguchi, Y., Angata, T., Eds.; Springer Japan: Tokyo, Japan, 2014; pp. 233-246.

38. Shoreibah, M.; Perng, G.S.; Adler, B.; Weinstein, J.; Basu, R.; Cupples, R.; Wen, D.; Browne, J.K.; Buckhaults, P.; Fregien, N.; et al. Isolation, characterization, and expression of a cdna encoding $N$-acetylglucosaminyltransferase V. J. Biol. Chem. 1993, 268, 15381-15385. [PubMed]

39. Shoreibah, M.G.; Hindsgaul, O.; Pierce, M. Purification and characterization of rat kidney udp-N-acetylglucosamine: Alpha-6-d-mannoside beta-1,6-N-acetylglucosaminyltransferase. J. Biol. Chem. 1992, 267, 2920-2927. [PubMed]

40. Dennis, J.W.; Nabi, I.R.; Demetriou, M. Metabolism, cell surface organization, and disease. Cell 2009, 139, 1229-1241. [CrossRef] [PubMed]

41. Boscher, C.; Dennis, J.W.; Nabi, I.R. Glycosylation, galectins and cellular signaling. Curr. Opin. Cell Biol. 2011, 23, 383-392. [CrossRef] [PubMed]

42. Ihara, S.; Miyoshi, E.; Ko, J.H.; Murata, K.; Nakahara, S.; Honke, K.; Dickson, R.B.; Lin, C.Y.; Taniguchi, N. Prometastatic effect of $\mathrm{N}$-acetylglucosaminyltransferase $\mathrm{v}$ is due to modification and stabilization of active matriptase by adding beta 1-6 glcnac branching. J. Biol. Chem. 2002, 277, 16960-16967. [CrossRef] [PubMed]

43. Ihara, S.; Miyoshi, E.; Nakahara, S.; Sakiyama, H.; Ihara, H.; Akinaga, A.; Honke, K.; Dickson, R.B.; Lin, C.Y.; Taniguchi, N. Addition of beta1-6 glcnac branching to the oligosaccharide attached to asn 772 in the serine protease domain of matriptase plays a pivotal role in its stability and resistance against trypsin. Glycobiology 2004, 14, 139-146. [CrossRef] [PubMed]

44. Carvalho, S.; Catarino, T.A.; Dias, A.M.; Kato, M.; Almeida, A.; Hessling, B.; Figueiredo, J.; Gartner, F.; Sanches, J.M.; Ruppert, T.; et al. Preventing e-cadherin aberrant $\mathrm{N}$-glycosylation at asn-554 improves its critical function in gastric cancer. Oncogene 2016, 35, 1619-1631. [CrossRef]

45. Guo, H.B.; Johnson, H.; Randolph, M.; Pierce, M. Regulation of homotypic cell-cell adhesion by branched $\mathrm{N}$-glycosylation of $\mathrm{N}$-cadherin extracellular ec2 and ec3 domains. J. Biol. Chem. 2009, 284, 34986-34997. [CrossRef] [PubMed]

46. Pinho, S.S.; Figueiredo, J.; Cabral, J.; Carvalho, S.; Dourado, J.; Magalhaes, A.; Gartner, F.; Mendonfa, A.M.; Isaji, T.; Gu, J.; et al. E-cadherin and adherens-junctions stability in gastric carcinoma: Functional implications of glycosyltransferases involving $\mathrm{N}$-glycan branching biosynthesis, $\mathrm{N}$-acetylglucosaminyltransferases iii and v. Biochim. Biophys. Acta 2013, 1830, 2690-2700. [CrossRef] [PubMed] 
47. Saito, T.; Miyoshi, E.; Sasai, K.; Nakano, N.; Eguchi, H.; Honke, K.; Taniguchi, N. A secreted type of beta 1,6-N-acetylglucosaminyltransferase $\mathrm{v}(\mathrm{GnT}-\mathrm{V})$ induces tumor angiogenesis without mediation of glycosylation: A novel function of gnt-v distinct from the original glycosyltransferase activity. J. Biol. Chem. 2002, 277, 17002-17008. [CrossRef] [PubMed]

48. Yanagi, M.; Aoyagi, Y.; Suda, T.; Mita, Y.; Asakura, H. N-acetylglucosaminyltransferase V as a possible aid for the evaluation of tumor invasiveness in patients with hepatocellular carcinoma. J. Gastroenterol. Hepatol. 2001, 16, 1282-1289. [CrossRef] [PubMed]

49. Ohtsubo, K.; Marth, J.D. Glycosylation in cellular mechanisms of health and disease. Cell 2006, 126, 855-867. [CrossRef] [PubMed]

50. Kuhn, P.H.; Voss, M.; Haug-Kroper, M.; Schroder, B.; Schepers, U.; Brase, S.; Haass, C.; Lichtenthaler, S.F.; Fluhrer, R. Secretome analysis identifies novel signal peptide peptidase-like 3 (SPPL3) substrates and reveals a role of SPPL3 in multiple Golgi glycosylation pathways. Mol. Cell. Proteomics 2015, 14, 1584-1598. [CrossRef] [PubMed]

51. Voss, M.; Kunzel, U.; Higel, F.; Kuhn, P.H.; Colombo, A.; Fukumori, A.; Haug-Kroper, M.; Klier, B.; Grammer, G.; Seidl, A.; et al. Shedding of glycan-modifying enzymes by signal peptide peptidase-like 3 (SPPL3) regulates cellular N-glycosylation. EMBO J. 2014, 33, 2890-2905. [CrossRef] [PubMed]

52. Granovsky, M.; Fata, J.; Pawling, J.; Muller, W.J.; Khokha, R.; Dennis, J.W. Suppression of tumor growth and metastasis in mgat5-deficient mice. Nat. Med. 2000, 6, 306-312. [PubMed]

53. Guo, H.B.; Johnson, H.; Randolph, M.; Nagy, T.; Blalock, R.; Pierce, M. Specific posttranslational modification regulates early events in mammary carcinoma formation. Proc. Natl. Acad. Sci. USA 2010, 107, 21116-21121. [CrossRef] [PubMed]

54. Tian, H.; Miyoshi, E.; Kawaguchi, N.; Shaker, M.; Ito, Y.; Taniguchi, N.; Tsujimoto, M.; Matsuura, N. The implication of $N$-acetylglucosaminyltransferase v expression in gastric cancer. Pathobiology 2008, 75, 288-294. [CrossRef] [PubMed]

55. Ishibashi, Y.; Dosaka-Akita, H.; Miyoshi, E.; Shindoh, M.; Miyamoto, M.; Kinoshita, I.; Miyazaki, H.; Itoh, T.; Kondo, S.; Nishimura, M.; et al. Expression of $\mathrm{N}$-acetylglucosaminyltransferase $\mathrm{V}$ in the development of human esophageal cancers: Immunohistochemical data from carcinomas and nearby noncancerous lesions. Oncology 2005, 69, 301-310. [CrossRef] [PubMed]

56. Guo, H.; Nagy, T.; Pierce, M. Post-translational glycoprotein modifications regulate colon cancer stem cells and colon adenoma progression in apc $(\mathrm{min} /+)$ mice through altered wnt receptor signaling. J. Biol. Chem. 2014, 289, 31534-31549. [CrossRef] [PubMed]

57. Ito, Y.; Miyoshi, E.; Sakon, M.; Takeda, T.; Noda, K.; Tsujimoto, M.; Ito, S.; Honda, H.; Takemura, F.; Wakasa, K.; et al. Elevated expression of UDP-N-acetylglucosamine: Alphamannoside beta1,6 $\mathrm{N}$-acetylglucosaminyltransferase is an early event in hepatocarcinogenesis. Int. J. Cancer 2001, 91, 631-637. [CrossRef]

58. Handerson, T.; Camp, R.; Harigopal, M.; Rimm, D.; Pawelek, J. Beta1,6-branched oligosaccharides are increased in lymph node metastases and predict poor outcome in breast carcinoma. Clin. Cancer Res. 2005, 11, 2969-2973. [CrossRef] [PubMed]

59. Inamori, K.; Endo, T.; Ide, Y.; Fujii, S.; Gu, J.; Honke, K.; Taniguchi, N. Molecular cloning and characterization of human gnt-ix, a novel beta1,6-N-acetylglucosaminyltransferase that is specifically expressed in the brain. J. Biol. Chem. 2003, 278, 43102-43109. [CrossRef] [PubMed]

60. Kaneko, M.; Alvarez-Manilla, G.; Kamar, M.; Lee, I.; Lee, J.K.; Troupe, K.; Zhang, W.; Osawa, M.; Pierce, M. A novel beta(1,6)-N-acetylglucosaminyltransferase v (GnT-Vb)(1). FEBS Lett. 2003, 554, 515-519. [CrossRef]

61. Alvarez-Manilla, G.; Troupe, K.; Fleming, M.; Martinez-Uribe, E.; Pierce, M. Comparison of the substrate specificities and catalytic properties of the sister $N$-acetylglucosaminyltransferases, GnT-V and GnT-Vb (IX). Glycobiology 2010, 20, 166-174. [CrossRef] [PubMed]

62. Inamori, K.; Endo, T.; Gu, J.; Matsuo, I.; Ito, Y.; Fujii, S.; Iwasaki, H.; Narimatsu, H.; Miyoshi, E.; Honke, K.; et al. $\mathrm{N}$-acetylglucosaminyltransferase ix acts on the glcnac beta 1,2-man alpha 1-ser/thr moiety, forming a 2,6-branched structure in brain O-mannosyl glycan. J. Biol. Chem. 2004, 279, 2337-2340. [CrossRef] [PubMed]

63. Inamori, K.-I.; Pierce, M.; Taniguchi, N. Mannosyl (alpha-1,6-)-glycoprotein beta-1,6-N-acetylglucosaminyltransferase, isozyme b (mgat5b). In Handbook of Glycosyltransferases and Related Genes; Taniguchi, N., Honke, K., Fukuda, M., Narimatsu, H., Yamaguchi, Y., Angata, T., Eds.; Springer Japan: Tokyo, Japan, 2014; pp. 247-255. 
64. Kizuka, Y.; Kitazume, S.; Okahara, K.; Villagra, A.; Sotomayor, E.M.; Taniguchi, N. Epigenetic regulation of a brain-specific glycosyltransferase $N$-acetylglucosaminyltransferase-ix (GnT-IX) by specific chromatin modifiers. J. Biol. Chem. 2014, 289, 11253-11261. [CrossRef] [PubMed]

65. Kizuka, Y.; Kitazume, S.; Yoshida, M.; Taniguchi, N. Brain-specific expression of $N$-acetylglucosaminyltransferase ix (GnT-IX) is regulated by epigenetic histone modifications. J. Biol. Chem. 2011, 286, 31875-31884. [CrossRef] [PubMed]

66. Kanekiyo, K.; Inamori, K.; Kitazume, S.; Sato, K.; Maeda, J.; Higuchi, M.; Kizuka, Y.; Korekane, H.; Matsuo, I.; Honke, K.; et al. Loss of branched $o$-mannosyl glycans in astrocytes accelerates remyelination. J. Neurosci. 2013, 33, 10037-10047. [CrossRef] [PubMed]

67. Abbott, K.L.; Matthews, R.T.; Pierce, M. Receptor tyrosine phosphatase beta (RPTPbeta) activity and signaling are attenuated by glycosylation and subsequent cell surface galectin-1 binding. J. Biol. Chem. 2008, 283, 33026-33035. [CrossRef] [PubMed]

68. Lommel, M.; Winterhalter, P.R.; Willer, T.; Dahlhoff, M.; Schneider, M.R.; Bartels, M.F.; Renner-Muller, I.; Ruppert, T.; Wolf, E.; Strahl, S. Protein O-mannosylation is crucial for e-cadherin-mediated cell adhesion. Proc. Natl. Acad. Sci. USA 2013, 110, 21024-21029. [CrossRef] [PubMed]

69. Vester-Christensen, M.B.; Halim, A.; Joshi, H.J.; Steentoft, C.; Bennett, E.P.; Levery, S.B.; Vakhrushev, S.Y.; Clausen, $\mathrm{H}$. Mining the $\mathrm{O}$-mannose glycoproteome reveals cadherins as major $O$-mannosylated glycoproteins. Proc. Natl. Acad. Sci. USA 2013, 110, 21018-21023. [CrossRef] [PubMed]

70. Endo, T. Glycobiology of alpha-dystroglycan and muscular dystrophy. J. Biochem. 2015, 157, 1-12. [CrossRef] [PubMed]

71. Kanagawa, M.; Kobayashi, K.; Tajiri, M.; Manya, H.; Kuga, A.; Yamaguchi, Y.; Akasaka-Manya, K.; Furukawa, J.; Mizuno, M.; Kawakami, H.; et al. Identification of a post-translational modification with ribitol-phosphate and its defect in muscular dystrophy. Cell Rep. 2016, 14, 2209-2223. [CrossRef] [PubMed]

72. Inamori, K.; Gu, J.; Ohira, M.; Kawasaki, A.; Nakamura, Y.; Nakagawa, T.; Kondo, A.; Miyoshi, E.; Nakagawara, A.; Taniguchi, N. High expression of $N$-acetylglucosaminyltransferase V in favorable neuroblastomas: Involvement of its effect on apoptosis. FEBS Lett. 2006, 580, 627-632. [CrossRef]

73. Lange, T.; Ullrich, S.; Muller, I.; Nentwich, M.F.; Stubke, K.; Feldhaus, S.; Knies, C.; Hellwinkel, O.J.; Vessella, R.L.; Abramjuk, C.; et al. Human prostate cancer in a clinically relevant xenograft mouse model: Identification of beta(1,6)-branched oligosaccharides as a marker of tumor progression. Clin. Cancer Res. 2012, 18, 1364-1373. [CrossRef]

74. Vojta, A.; Samarzija, I.; Bockor, L.; Zoldos, V. Glyco-genes change expression in cancer through aberrant methylation. Biochim. Biophys. Acta. 2016. [CrossRef]

75. Ohtsubo, K.; Taniguchi, N. Mannosyl (alpha-1,3-)-glycoprotein beta-1,4-N-acetylglucosaminyltransferase, isozyme a,b (mgat4a,b). In Handbook of Glycosyltransferases and Related Genes; Taniguchi, N., Honke, K., Fukuda, M., Narimatsu, H., Yamaguchi, Y., Angata, T., Eds.; Springer Japan: Tokyo, Japan, 2014; pp. $223-232$.

76. Oguri, S.; Minowa, M.T.; Ihara, Y.; Taniguchi, N.; Ikenaga, H.; Takeuchi, M. Purification and characterization of udp- $N$-acetylglucosamine: Alpha1,3-d-mannoside beta1,4- $N$-acetylglucosaminyltransferase (N-acetylglucosaminyltransferase-iv) from bovine small intestine. J. Biol. Chem. 1997, 272, 22721-22727. [CrossRef] [PubMed]

77. Minowa, M.T.; Oguri, S.; Yoshida, A.; Hara, T.; Iwamatsu, A.; Ikenaga, H.; Takeuchi, M. Cdna cloning and expression of bovine udp- $N$-acetylglucosamine: Alpha1, 3-d-mannoside beta1,4- $N$ acetylglucosaminyltransferase iv. J. Biol. Chem. 1998, 273, 11556-11562. [CrossRef] [PubMed]

78. Takamatsu, S.; Antonopoulos, A.; Ohtsubo, K.; Ditto, D.; Chiba, Y.; Le, D.T.; Morris, H.R.; Haslam, S.M.; Dell, A.; Marth, J.D.; et al. Physiological and glycomic characterization of $N$-acetylglucosaminyltransferase- IVa and -IVb double deficient mice. Glycobiology 2010, 20, 485-497. [CrossRef] [PubMed]

79. Oguri, S.; Yoshida, A.; Minowa, M.T.; Takeuchi, M. Kinetic properties and substrate specificities of two recombinant human $\mathrm{N}$-acetylglucosaminyltransferase-IV isozymes. Glycoconj. J. 2006, 23, 473-480. [CrossRef] [PubMed]

80. Ohtsubo, K.; Takamatsu, S.; Minowa, M.T.; Yoshida, A.; Takeuchi, M.; Marth, J.D. Dietary and genetic control of glucose transporter 2 glycosylation promotes insulin secretion in suppressing diabetes. Cell 2005, 123, 1307-1321. [CrossRef] [PubMed] 
81. Niimi, K.; Yamamoto, E.; Fujiwara, S.; Shinjo, K.; Kotani, T.; Umezu, T.; Kajiyama, H.; Shibata, K.; Ino, K.; Kikkawa, F. High expression of $\mathrm{N}$-acetylglucosaminyltransferase iva promotes invasion of choriocarcinoma. Br. J. Cancer. 2012, 107, 1969-1977. [CrossRef] [PubMed]

82. Ide, Y.; Miyoshi, E.; Nakagawa, T.; Gu, J.; Tanemura, M.; Nishida, T.; Ito, T.; Yamamoto, H.; Kozutsumi, Y.; Taniguchi, N. Aberrant expression of $N$-acetylglucosaminyltransferase-iva and ivb (GnT-IVa and b) in pancreatic cancer. Biochem. Biophys. Res. Commun 2006, 341, 478-482. [CrossRef] [PubMed]

83. Fan, J.; Wang, S.; Yu, S.; He, J.; Zheng, W.; Zhang, J. N-acetylglucosaminyltransferase IVa regulates metastatic potential of mouse hepatocarcinoma cells through glycosylation of cd147. Glycoconj. J. 2012, 29, 323-334. [CrossRef] [PubMed]

84. Ohtsubo, K.; Chen, M.Z.; Olefsky, J.M.; Marth, J.D. Pathway to diabetes through attenuation of pancreatic beta cell glycosylation and glucose transport. Nat. Med. 2011, 17, 1067-1075. [CrossRef] [PubMed]

85. Ebrahim, A.H.; Alalawi, Z.; Mirandola, L.; Rakhshanda, R.; Dahlbeck, S.; Nguyen, D.; Jenkins, M.; Grizzi, F.; Cobos, E.; Figueroa, J.A.; et al. Galectins in cancer: Carcinogenesis, diagnosis and therapy. Ann. Transl. Med. 2014, 2, 88. [PubMed]

86. Ihara, H.; Tsukamoto, H.; Gu, J.; Miyoshi, E.; Taniguchi, N.; Ikeda, Y. Fucosyltransferase 8. Gdp-fucose $N$-glycan core $\alpha 6$-fucosyltransferase (fut8). In Handbook of Glycosyltransferases and Related Genes; Taniguchi, N., Honke, K., Fukuda, M., Narimatsu, H., Yamaguchi, Y., Angata, T., Eds.; Springer Japan: Tokyo, Japan, 2014; pp. 581-596.

87. Takahashi, M.; Kuroki, Y.; Ohtsubo, K.; Taniguchi, N. Core fucose and bisecting glcnac, the direct modifiers of the $N$-glycan core: Their functions and target proteins. Carbohydr. Res. 2009, 344, 1387-1390. [CrossRef] [PubMed]

88. Brockhausen, I.; Narasimhan, S.; Schachter, H. The biosynthesis of highly branched N-glycans: Studies on the sequential pathway and functional role of $\mathrm{N}$-acetylglucosaminyltransferases I, II, III, IV, V and VI. Biochimie 1988, 70, 1521-1533. [CrossRef]

89. Uozumi, N.; Yanagidani, S.; Miyoshi, E.; Ihara, Y.; Sakuma, T.; Gao, C.X.; Teshima, T.; Fujii, S.; Shiba, T.; Taniguchi, N. Purification and cDNA cloning of porcine brain GDP-L-Fuc: N-acetyl-beta-d-glucosaminide alpha1->6fucosyltransferase. J. Biol. Chem. 1996, 271, 27810-27817. [CrossRef] [PubMed]

90. Yanagidani, S.; Uozumi, N.; Ihara, Y.; Miyoshi, E.; Yamaguchi, N.; Taniguchi, N. Purification and cdna cloning of gdp-l-fuc: N-acetyl-beta-d-glucosaminide:Alpha1-6 fucosyltransferase (alpha1-6 fuct) from human gastric cancer MKN45 cells. J. Biochem. 1997, 121, 626-632. [CrossRef] [PubMed]

91. Miyoshi, E.; Uozumi, N.; Noda, K.; Hayashi, N.; Hori, M.; Taniguchi, N. Expression of alpha1-6 fucosyltransferase in rat tissues and human cancer cell lines. Int. J. Cancer 1997, 72, 1117-1121. [CrossRef]

92. Noda, K.; Miyoshi, E.; Uozumi, N.; Gao, C.X.; Suzuki, K.; Hayashi, N.; Hori, M.; Taniguchi, N. High expression of alpha-1-6 fucosyltransferase during rat hepatocarcinogenesis. Int. J. Cancer 1998, 75, 444-450. [CrossRef]

93. Honma, R.; Kinoshita, I.; Miyoshi, E.; Tomaru, U.; Matsuno, Y.; Shimizu, Y.; Takeuchi, S.; Kobayashi, Y.; Kaga, K.; Taniguchi, N.; et al. Expression of fucosyltransferase 8 is associated with an unfavorable clinical outcome in non-small cell lung cancers. Oncology 2015, 88, 298-308. [CrossRef] [PubMed]

94. Chen, C.Y.; Jan, Y.H.; Juan, Y.H.; Yang, C.J.; Huang, M.S.; Yu, C.J.; Yang, P.C.; Hsiao, M.; Hsu, T.L.; Wong, C.H. Fucosyltransferase 8 as a functional regulator of nonsmall cell lung cancer. Proc. Natl. Acad. Sci. USA 2013, 110, 630-635. [CrossRef] [PubMed]

95. Wang, X.; Inoue, S.; Gu, J.; Miyoshi, E.; Noda, K.; Li, W.; Mizuno-Horikawa, Y.; Nakano, M.; Asahi, M.; Takahashi, M.; et al. Dysregulation of TGF-beta1 receptor activation leads to abnormal lung development and emphysema-like phenotype in core fucose-deficient mice. Proc. Natl. Acad. Sci. USA 2005, 102, 15791-15796. [CrossRef] [PubMed]

96. Gao, C.; Maeno, T.; Ota, F.; Ueno, M.; Korekane, H.; Takamatsu, S.; Shirato, K.; Matsumoto, A.; Kobayashi, S.; Yoshida, K.; et al. Sensitivity of heterozygous alpha1,6-fucosyltransferase knock-out mice to cigarette smoke-induced emphysema: Implication of aberrant transforming growth factor-beta signaling and matrix metalloproteinase gene expression. J. Biol. Chem. 2012, 287, 16699-16708. [CrossRef] [PubMed]

97. Fukuda, T.; Hashimoto, H.; Okayasu, N.; Kameyama, A.; Onogi, H.; Nakagawasai, O.; Nakazawa, T.; Kurosawa, T.; Hao, Y.; Isaji, T.; et al. Alpha1,6-fucosyltransferase-deficient mice exhibit multiple behavioral abnormalities associated with a schizophrenia-like phenotype: Importance of the balance between the dopamine and serotonin systems. J. Biol. Chem. 2011, 286, 18434-18443. [CrossRef] [PubMed] 
98. Gu, W.; Fukuda, T.; Isaji, T.; Hang, Q.; Lee, H.H.; Sakai, S.; Morise, J.; Mitoma, J.; Higashi, H.; Taniguchi, N.; et al. Loss of alpha1,6-fucosyltransferase decreases hippocampal long term potentiation: Implications for core fucosylation in the regulation of ampa receptor heteromerization and cellular signaling. J. Biol. Chem. 2015, 290, 17566-17575. [CrossRef] [PubMed]

99. Li, W.; Yu, R.; Ma, B.; Yang, Y.; Jiao, X.; Liu, Y.; Cao, H.; Dong, W.; Liu, L.; Ma, K.; et al. Core fucosylation of IGG $\mathrm{b}$ cell receptor is required for antigen recognition and antibody production. J. Immunol. 2015, 194, 2596-2606. [CrossRef] [PubMed]

100. Fujii, H.; Shinzaki, S.; Iijima, H.; Wakamatsu, K.; Iwamoto, C.; Sobajima, T.; Kuwahara, R.; Hiyama, S.; Hayashi, Y.; Takamatsu, S.; et al. Core fucosylation on T cells, required for activation of T-cell receptor signaling and induction of colitis in mice, is increased in patients with inflammatory bowel disease. Gastroenterology 2016, 150. [CrossRef] [PubMed]

101. Wang, X.; Gu, J.; Ihara, H.; Miyoshi, E.; Honke, K.; Taniguchi, N. Core fucosylation regulates epidermal growth factor receptor-mediated intracellular signaling. J. Biol. Chem. 2006, 281, 2572-2577. [CrossRef] [PubMed]

102. Liu, Y.C.; Yen, H.Y.; Chen, C.Y.; Chen, C.H.; Cheng, P.F.; Juan, Y.H.; Chen, C.H.; Khoo, K.H.; Yu, C.J.; Yang, P.C.; et al. Sialylation and fucosylation of epidermal growth factor receptor suppress its dimerization and activation in lung cancer cells. Proc. Natl. Acad. Sci. USA 2011, 108, 11332-11337. [CrossRef] [PubMed]

103. Wang, Y.; Fukuda, T.; Isaji, T.; Lu, J.; Gu, W.; Lee, H.H.; Ohkubo, Y.; Kamada, Y.; Taniguchi, N.; Miyoshi, E.; et al. Loss of alpha1,6-fucosyltransferase suppressed liver regeneration: Implication of core fucose in the regulation of growth factor receptor-mediated cellular signaling. Sci. Rep. 2015, 5, 8264. [CrossRef] [PubMed]

104. Wang, Y.; Fukuda, T.; Isaji, T.; Lu, J.; Im, S.; Hang, Q.; Gu, W.; Hou, S.; Ohtsubo, K.; Gu, J. Loss of alpha1,6-fucosyltransferase inhibits chemical-induced hepatocellular carcinoma and tumorigenesis by down-regulating several cell signaling pathways. FASEB J. 2015, 29, 3217-3227. [CrossRef] [PubMed]

105. Potapenko, I.O.; Haakensen, V.D.; Luders, T.; Helland, A.; Bukholm, I.; Sorlie, T.; Kristensen, V.N.; Lingjaerde, O.C.; Borresen-Dale, A.L. Glycan gene expression signatures in normal and malignant breast tissue; possible role in diagnosis and progression. Mol. Oncol. 2010, 4, 98-118. [CrossRef] [PubMed]

106. Wang, X.; Chen, J.; Li, Q.K.; Peskoe, S.B.; Zhang, B.; Choi, C.; Platz, E.A.; Zhang, H. Overexpression of alpha $(1,6)$ fucosyltransferase associated with aggressive prostate cancer. Glycobiology 2014, 24, 935-944. [CrossRef] [PubMed]

107. Saldova, R.; Fan, Y.; Fitzpatrick, J.M.; Watson, R.W.; Rudd, P.M. Core fucosylation and alpha2-3 sialylation in serum $\mathrm{N}$-glycome is significantly increased in prostate cancer comparing to benign prostate hyperplasia. Glycobiology 2011, 21, 195-205. [CrossRef] [PubMed]

108. Taketa, K.; Endo, Y.; Sekiya, C.; Tanikawa, K.; Koji, T.; Taga, H.; Satomura, S.; Matsuura, S.; Kawai, T.; Hirai, H. A collaborative study for the evaluation of lectin-reactive alpha-fetoproteins in early detection of hepatocellular carcinoma. Cancer Res. 1993, 53, 5419-5423. [PubMed]

109. Toyoda, H.; Kumada, T.; Tada, T. Highly sensitive lens culinaris agglutinin-reactive alpha-fetoprotein: A new tool for the management of hepatocellular carcinoma. Oncology 2011, $81 \mathrm{Suppl} \mathrm{1,61-65.} \mathrm{[CrossRef]} \mathrm{[PubMed]}$

110. Abelev, G.I. Alpha-fetoprotein in ontogenesis and its association with malignant tumors. Adv. Cancer Res. 1971, 14, 295-358. [PubMed]

111. Nakagawa, T.; Miyoshi, E.; Yakushijin, T.; Hiramatsu, N.; Igura, T.; Hayashi, N.; Taniguchi, N.; Kondo, A. Glycomic analysis of alpha-fetoprotein L3 in hepatoma cell lines and hepatocellular carcinoma patients. J. Proteome Res. 2008, 7, 2222-2233. [CrossRef] [PubMed]

112. Miyoshi, E.; Moriwaki, K.; Terao, N.; Tan, C.C.; Terao, M.; Nakagawa, T.; Matsumoto, H.; Shinzaki, S.; Kamada, Y. Fucosylation is a promising target for cancer diagnosis and therapy. Biomolecules 2012, 2, 34-45. [CrossRef] [PubMed]

113. Okuyama, N.; Ide, Y.; Nakano, M.; Nakagawa, T.; Yamanaka, K.; Moriwaki, K.; Murata, K.; Ohigashi, H.; Yokoyama, S.; Eguchi, H.; et al. Fucosylated haptoglobin is a novel marker for pancreatic cancer: A detailed analysis of the oligosaccharide structure and a possible mechanism for fucosylation. Int. J. Cancer 2006, 118, 2803-2808. [CrossRef] [PubMed]

114. Takahashi, S.; Sugiyama, T.; Shimomura, M.; Kamada, Y.; Fujita, K.; Nonomura, N.; Miyoshi, E.; Nakano, M. Site-specific and linkage analyses of fucosylated $\mathrm{N}$-glycans on haptoglobin in sera of patients with various types of cancer: Possible implication for the differential diagnosis of cancer. Glycoconj. J. 2016, 33. [CrossRef] [PubMed] 
115. Shuptrine, C.W.; Surana, R.; Weiner, L.M. Monoclonal antibodies for the treatment of cancer. Semin. Cancer Biol. 2012, 22, 3-13. [CrossRef] [PubMed]

116. Shields, R.L.; Lai, J.; Keck, R.; O'Connell, L.Y.; Hong, K.; Meng, Y.G.; Weikert, S.H.; Presta, L.G. Lack of fucose on human IGG1 N-linked oligosaccharide improves binding to human Fcgamma RIII and antibody-dependent cellular toxicity. J. Biol. Chem. 2002, 277, 26733-26740. [CrossRef] [PubMed]

117. Shinkawa, T.; Nakamura, K.; Yamane, N.; Shoji-Hosaka, E.; Kanda, Y.; Sakurada, M.; Uchida, K.; Anazawa, H.; Satoh, M.; Yamasaki, M.; et al. The absence of fucose but not the presence of galactose or bisecting $\mathrm{N}$-acetylglucosamine of human IGG1 complex-type oligosaccharides shows the critical role of enhancing antibody-dependent cellular cytotoxicity. J. Biol. Chem. 2003, 278, 3466-3473. [CrossRef] [PubMed]

118. Reusch, D.; Tejada, M.L. Fc glycans of therapeutic antibodies as critical quality attributes. Glycobiology 2015, 25, 1325-1334. [CrossRef] [PubMed]

119. Costa, A.R.; Rodrigues, M.E.; Henriques, M.; Oliveira, R.; Azeredo, J. Glycosylation: Impact, control and improvement during therapeutic protein production. Crit. Rev. Biotechnol. 2014, 34, 281-299. [CrossRef] [PubMed]

120. Buckhaults, P.; Chen, L.; Fregien, N.; Pierce, M. Transcriptional regulation of N-acetylglucosaminyltransferase V by the src oncogene. J. Biol. Chem. 1997, 272, 19575-19581. [CrossRef] [PubMed]

121. Chen, L.; Zhang, W.; Fregien, N.; Pierce, M. The her-2/neu oncogene stimulates the transcription of $\mathrm{N}$-acetylglucosaminyltransferase $\mathrm{V}$ and expression of its cell surface oligosaccharide products. Oncogene 1998, 17, 2087-2093. [CrossRef] [PubMed]

122. Kang, R.; Saito, H.; Ihara, Y.; Miyoshi, E.; Koyama, N.; Sheng, Y.; Taniguchi, N. Transcriptional regulation of the $\mathrm{N}$-acetylglucosaminyltransferase $\mathrm{V}$ gene in human bile duct carcinoma cells (HuCC-T1) is mediated by ets-1. J. Biol. Chem. 1996, 271, 26706-26712. [PubMed]

123. Ko, J.H.; Miyoshi, E.; Noda, K.; Ekuni, A.; Kang, R.; Ikeda, Y.; Taniguchi, N. Regulation of the GnT-V promoter by transcription factor Ets-1 in various cancer cell lines. J. Biol. Chem. 1999, 274, 22941-22948. [CrossRef] [PubMed]

124. Lauc, G.; Essafi, A.; Huffman, J.E.; Hayward, C.; Knezevic, A.; Kattla, J.J.; Polasek, O.; Gornik, O.; Vitart, V.; Abrahams, J.L.; et al. Genomics meets glycomics-the first gwas study of human N-glycome identifies HNF1alpha as a master regulator of plasma protein fucosylation. PLoS Genet. 2010, 6, e1001256. [CrossRef] [PubMed]

125. Akama, R.; Sato, Y.; Kariya, Y.; Isaji, T.; Fukuda, T.; Lu, L.; Taniguchi, N.; Ozawa, M.; Gu, J. $\mathrm{N}$-acetylglucosaminyltransferase III expression is regulated by cell-cell adhesion via the e-cadherincatenin-actin complex. Proteomics 2008, 8, 3221-3228. [CrossRef] [PubMed]

126. Xu, Q.; Akama, R.; Isaji, T.; Lu, Y.; Hashimoto, H.; Kariya, Y.; Fukuda, T.; Du, Y.; Gu, J. Wnt/beta-catenin signaling down-regulates $N$-acetylglucosaminyltransferase III expression: The implications of two mutually exclusive pathways for regulation. J. Biol. Chem. 2011, 286, 4310-4318. [CrossRef] [PubMed]

127. Kurimoto, A.; Kitazume, S.; Kizuka, Y.; Nakajima, K.; Oka, R.; Fujinawa, R.; Korekane, H.; Yamaguchi, Y.; Wada, Y.; Taniguchi, N. The absence of core fucose up-regulates GnT-III and WNT target genes: A possible mechanism for an adaptive response in terms of glycan function. J. Biol. Chem. 2014, 289, 11704-11714. [CrossRef] [PubMed]

128. Bonasio, R.; Tu, S.; Reinberg, D. Molecular signals of epigenetic states. Science 2010, 330, 612-616. [CrossRef] [PubMed]

129. Plass, C.; Pfister, S.M.; Lindroth, A.M.; Bogatyrova, O.; Claus, R.; Lichter, P. Mutations in regulators of the epigenome and their connections to global chromatin patterns in cancer. Nat. Rev. Genet. 2013, 14, 765-780. [CrossRef] [PubMed]

130. Bergman, Y.; Cedar, H. DNA methylation dynamics in health and disease. Nat. Struct. Mol. Biol. 2013, 20, 274-281. [CrossRef] [PubMed]

131. Jeschke, J.; Collignon, E.; Fuks, F. Portraits of TET-mediated DNA hydroxymethylation in cancer. Curr. Opin. Genet. Dev. 2016, 36, 16-26. [CrossRef] [PubMed]

132. Anugraham, M.; Jacob, F.; Nixdorf, S.; Everest-Dass, A.V.; Heinzelmann-Schwarz, V.; Packer, N.H. Specific glycosylation of membrane proteins in epithelial ovarian cancer cell lines: Glycan structures reflect gene expression and DNA methylation status. Mol. Cell. Proteomics 2014, 13, 2213-2232. [CrossRef] [PubMed] 
133. Saldova, R.; Dempsey, E.; Perez-Garay, M.; Marino, K.; Watson, J.A.; Blanco-Fernandez, A.; Struwe, W.B.; Harvey, D.J.; Madden, S.F.; Peracaula, R.; et al. 5-aza-2'-deoxycytidine induced demethylation influences $\mathrm{N}$-glycosylation of secreted glycoproteins in ovarian cancer. Epigenetics 2011, 6, 1362-1372. [CrossRef] [PubMed]

134. Bannister, A.J.; Kouzarides, T. Regulation of chromatin by histone modifications. Cell Res. 2011, 21, $381-395$. [CrossRef] [PubMed]

135. Lauc, G.; Vojta, A.; Zoldos, V. Epigenetic regulation of glycosylation is the quantum mechanics of biology. Biochim. Biophys. Acta. 2014, 1840, 65-70. [CrossRef] [PubMed]

136. Morris, K.V.; Mattick, J.S. The rise of regulatory rna. Nat. Rev. Genet. 2014, 15, 423-437. [CrossRef] [PubMed]

137. Wang, M.; Wang, J.; Kong, X.; Chen, H.; Wang, Y.; Qin, M.; Lin, Y.; Chen, H.; Xu, J.; Hong, J.; et al. Mir-198 represses tumor growth and metastasis in colorectal cancer by targeting fucosyl transferase 8. Sci. Rep. 2014, 4, 6145. [CrossRef] [PubMed]

138. Bernardi, C.; Soffientini, U.; Piacente, F.; Tonetti, M.G. Effects of micrornas on fucosyltransferase 8 (FUT8) expression in hepatocarcinoma cells. PLoS ONE 2013, 8, e76540. [CrossRef] [PubMed]

139. Vaiana, C.A.; Kurcon, T.; Mahal, L.K. MicroRNA-424 predicts a role for beta-1,4 branched glycosylation in cell cycle progression. J. Biol. Chem. 2016, 291, 1529-1537. [CrossRef] [PubMed]

140. Kurcon, T.; Liu, Z.; Paradkar, A.V.; Vaiana, C.A.; Koppolu, S.; Agrawal, P.; Mahal, L.K. MiRNA proxy approach reveals hidden functions of glycosylation. Proc. Natl. Acad. Sci. USA 2015, 112, 7327-7332. [CrossRef] [PubMed]

141. Kasper, B.T.; Koppolu, S.; Mahal, L.K. Insights into mirna regulation of the human glycome. Biochem. Biophys. Res. Commun. 2014, 445, 774-779. [CrossRef] [PubMed]

142. Agrawal, P.; Kurcon, T.; Pilobello, K.T.; Rakus, J.F.; Koppolu, S.; Liu, Z.; Batista, B.S.; Eng, W.S.; Hsu, K.L.; Liang, Y.; et al. Mapping posttranscriptional regulation of the human glycome uncovers microrna defining the glycocode. Proc. Natl. Acad. Sci. USA 2014, 111, 4338-4343. [CrossRef] [PubMed]

143. Hart, G.W.; Slawson, C.; Ramirez-Correa, G.; Lagerlof, O. Cross talk between O-glcnacylation and phosphorylation: Roles in signaling, transcription, and chronic disease. Annu. Rev. Biochem. 2011, 80, 825-858. [CrossRef] [PubMed]

144. Sasai, K.; Ikeda, Y.; Fujii, T.; Tsuda, T.; Taniguchi, N. UDP-glcnac concentration is an important factor in the biosynthesis of beta1,6-branched oligosaccharides: Regulation based on the kinetic properties of $\mathrm{N}$-acetylglucosaminyltransferase v. Glycobiology 2002, 12, 119-127. [CrossRef] [PubMed]

145. Boroughs, L.K.; DeBerardinis, R.J. Metabolic pathways promoting cancer cell survival and growth. Nat. Cell Biol. 2015, 17, 351-359. [CrossRef] [PubMed]

146. Nakajima, K.; Kitazume, S.; Angata, T.; Fujinawa, R.; Ohtsubo, K.; Miyoshi, E.; Taniguchi, N. Simultaneous determination of nucleotide sugars with ion-pair reversed-phase hplc. Glycobiology 2010, 20, 865-871. [CrossRef] [PubMed]

147. Nakajima, K.; Ito, E.; Ohtsubo, K.; Shirato, K.; Takamiya, R.; Kitazume, S.; Angata, T.; Taniguchi, N. Mass isotopomer analysis of metabolically labeled nucleotide sugars and $\mathrm{N}$ - and $\mathrm{O}$-glycans for tracing nucleotide sugar metabolisms. Mol. Cell. Proteomics 2013, 12, 2468-2480. [CrossRef] [PubMed]

148. Korekane, H.; Park, J.Y.; Matsumoto, A.; Nakajima, K.; Takamatsu, S.; Ohtsubo, K.; Miyamoto, Y.; Hanashima, S.; Kanekiyo, K.; Kitazume, S.; et al. Identification of ectonucleotide pyrophosphatase/ phosphodiesterase 3 (ENPP3) as a regulator of $N$-acetylglucosaminyltransferase GnT-IX (GnT-Vb). J. Biol. Chem. 2013, 288, 27912-27926. [CrossRef] [PubMed]

149. Radhakrishnan, P.; Dabelsteen, S.; Madsen, F.B.; Francavilla, C.; Kopp, K.L.; Steentoft, C.; Vakhrushev, S.Y.; Olsen, J.V.; Hansen, L.; Bennett, E.P.; et al. Immature truncated O-glycophenotype of cancer directly induces oncogenic features. Proc. Natl. Acad. Sci. USA 2014, 111, E4066-E4075. [CrossRef] [PubMed]

150. Gill, D.J.; Tham, K.M.; Chia, J.; Wang, S.C.; Steentoft, C.; Clausen, H.; Bard-Chapeau, E.A.; Bard, F.A. Initiation of galnac-type $\mathrm{O}$-glycosylation in the endoplasmic reticulum promotes cancer cell invasiveness. Proc. Natl. Acad. Sci. USA 2013, 110, E3152-E3161. [CrossRef] [PubMed]

151. Sasai, K.; Ikeda, Y.; Ihara, H.; Honke, K.; Taniguchi, N. Caveolin-1 regulates the functional localization of $\mathrm{N}$-acetylglucosaminyltransferase III within the golgi apparatus. J. Biol. Chem. 2003, 278, 25295-25301. [CrossRef] [PubMed]

152. Wang, Z.; Wang, N.; Liu, P.; Peng, F.; Tang, H.; Chen, Q.; Xu, R.; Dai, Y.; Lin, Y.; Xie, X.; et al. Caveolin-1, a stress-related oncotarget, in drug resistance. Oncotarget 2015, 6, 37135-37150. [PubMed] 
153. Thaysen-Andersen, M.; Packer, N.H. Site-specific glycoproteomics confirms that protein structure dictates formation of N-glycan type, core fucosylation and branching. Glycobiology 2012, 22, 1440-1452. [CrossRef] [PubMed]

154. Sethi, M.K.; Kim, H.; Park, C.K.; Baker, M.S.; Paik, Y.K.; Packer, N.H.; Hancock, W.S.; Fanayan, S.; Thaysen-Andersen, M. In-depth $N$-glycome profiling of paired colorectal cancer and non-tumorigenic tissues reveals cancer-, stage- and EGFR-specific protein N-glycosylation. Glycobiology 2015, 25, 1064-1078. [CrossRef] [PubMed]

155. Moh, E.S.; Thaysen-Andersen, M.; Packer, N.H. Relative versus absolute quantitation in disease glycomics. Proteomics Clin. Appl. 2015, 9, 368-382. [CrossRef] [PubMed]

156. Levery, S.B.; Steentoft, C.; Halim, A.; Narimatsu, Y.; Clausen, H.; Vakhrushev, S.Y. Advances in mass spectrometry driven O-glycoproteomics. Biochim. Biophys. Acta 2015, 1850, 33-42. [CrossRef] [PubMed]

157. Laughlin, S.T.; Bertozzi, C.R. Imaging the glycome. Proc. Natl. Acad. Sci. USA 2009, 106, 12-17. [CrossRef] [PubMed]

158. Zhang, X.; Zhang, Y. Applications of azide-based bioorthogonal click chemistry in glycobiology. Molecules 2013, 18, 7145-7159. [CrossRef] [PubMed]

159. Rabuka, D.; Hubbard, S.C.; Laughlin, S.T.; Argade, S.P.; Bertozzi, C.R. A chemical reporter strategy to probe glycoprotein fucosylation. J. Am. Chem. Soc. 2006, 128, 12078-12079. [CrossRef] [PubMed]

160. Hanashima, S.; Inamori, K.; Manabe, S.; Taniguchi, N.; Ito, Y. Systematic synthesis of bisubstrate-type inhibitors of $N$-acetylglucosaminyltransferases. Chemistry 2006, 12, 3449-3462. [CrossRef] [PubMed]

161. Hanashima, S.; Korekane, H.; Taniguchi, N.; Yamaguchi, Y. Synthesis of N-glycan units for assessment of substrate structural requirements of $\mathrm{N}$-acetylglucosaminyltransferase III. Bioorg. Med. Chem. Lett. 2014, 24, 4533-4537. [CrossRef] [PubMed]

162. Ihara, H.; Ikeda, Y.; Toma, S.; Wang, X.; Suzuki, T.; Gu, J.; Miyoshi, E.; Tsukihara, T.; Honke, K.; Matsumoto, A.; et al. Crystal structure of mammalian alpha1,6-fucosyltransferase, FUT8. Glycobiology 2007, 17, 455-466. [CrossRef] [PubMed]

(C) 2016 by the authors; licensee MDPI, Basel, Switzerland. This article is an open access article distributed under the terms and conditions of the Creative Commons Attribution (CC-BY) license (http://creativecommons.org/licenses/by/4.0/). 